\title{
INTERACTIONS BETWEEN \\ ENERGY EFFICIENCY AND EMISSION TRADING \\ UNDER THE 1990 CLEAN AIR ACT AMENDMENTS
}

\author{
EDWARD L. HILLSMAN \\ Energy Division
}

Oak Ridge National Laboratory

DONALD R. ALVIC

Energy, Environment, and Resources Center

University of Tennessee-Knoxville

August, 1994

Sponsored by

Office of Energy Efficiency and Renewable Energy

U.S. Department of Energy

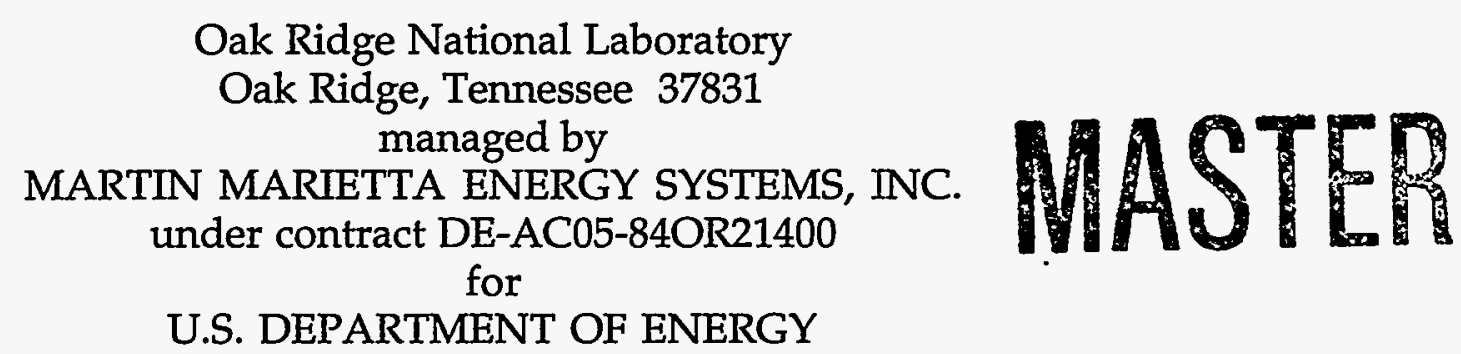

DISTRIBUTION OF THS DOCURENT IS UMLFAITES $D C C$ 
This report has been reproduced directly from the best available copy.

Available to DOE and DOE contractors from the Office of Scientific and Technical Information, P.O. Box 62, Oak Ridge, TN 37831; prices available from (615) 576-8401, FTS 626-8401.

Available to the public from the National Technical Information Service, U.S. Department of Commerce, 5285 Port Royal Rd., Springfield, VA 22161.

This report was prepared as an account of work sponsored by an agency of the United States Government. Neither the United States Government nor any agency thereof, nor any of their employees, makes any warranty, express or implied, or assumes any legal liability or responsibility for the accuracy, completeness, or usefulness of any information, apparatus, product, or process disclosed, or represents that its use would not infringe privately owned rights. Reference herein to any specific commercial product, process, or service by trade name, trademark, manufacturer, or otherwise, does not necessarily constitute or imply its endorsement, recommendation, or favoring by the United States Government or any agency thereof. The views and opinions of authors expressed herein do not necessarily state or reflect those of the United States Government or any agency thereof. 


\section{DISCLAIMER}

Portions of this document may be illegible in electronic image products. Images are produced from the best available original document. 


\section{CONTENTS}

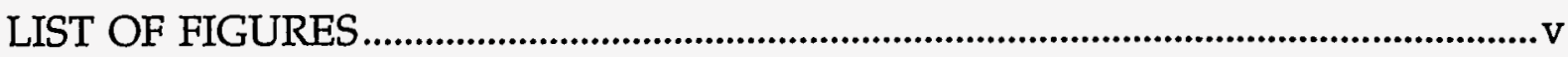

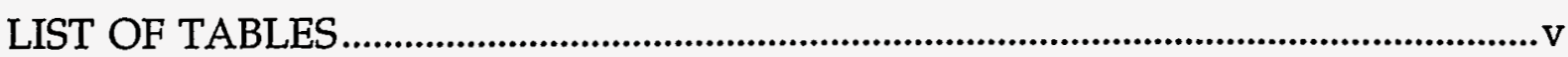

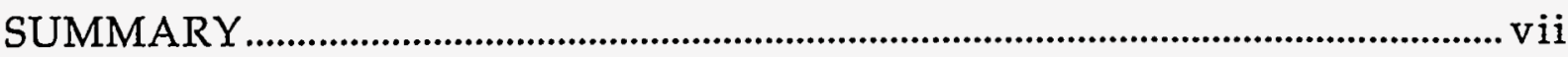

LIST OF ACRONYMS ...................................................................................................... ix

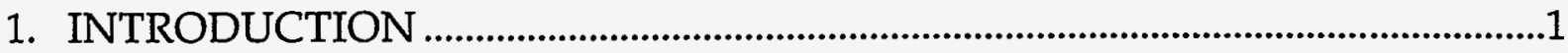

2. AN OVERVIEW OF THE $\mathrm{SO}_{2}$ EMISSION TRADING SYSTEM.............................3

Emission trading in principle .....................................................................................

A shift from regulating rates to capping emissions ..............................................4

3. ESTIMATING HOW ENERGY EFFICIENCY AND EMISSION TRADING

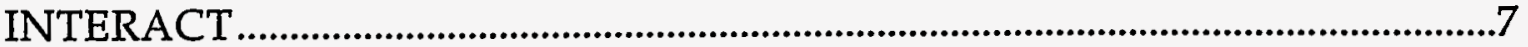

Major features and assumptions of the model ....................................................7

Scenario assumptions................................................................................................10

First scenario-Improve efficiency in nine states .......................................12

Second scenario-Improve efficiency in all states ...............................................17

Individual utilities ...................................................................................................19

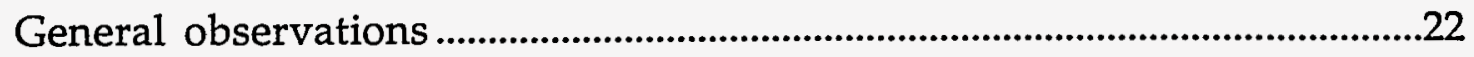

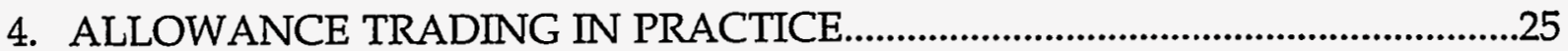

Incomplete regulations...................................................................................25

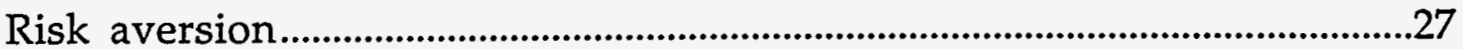

Other participants in the market..........................................................................28

Conclusions regarding trading and improved efficiency...................................30

5. OTHER INCENTIVES FOR END-USE EFFICIENCY .........................................31

Allowance reserve for conservation and renewable energy.............................31

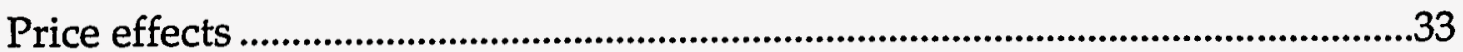

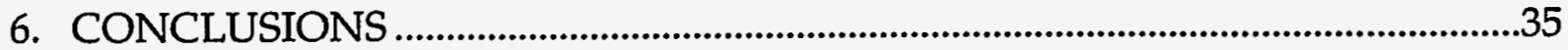

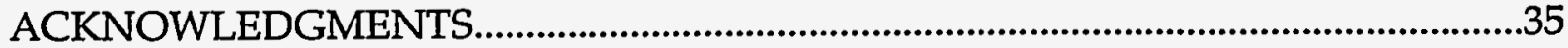

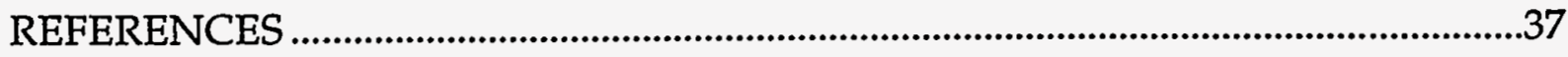




\section{.}




\section{LIST OF FIGURES}

Figure 1. Comparison of rate and tonnage limits on emissions as demand increases.

Figure 2. Increases in base-case emissions when conservation is limited to nine states. (States with no change in emissions are blank. States where emissions decreased have minus signs; see Figure 3 for amount of emission decrease)

Figure 3. Decreases in base-case emissions when conservation is limited to nine states. (States with no change in emissions are blank. States where emissions increased have plus signs; see Figure 2 for amount of emission increase)

Figure 4. Allowance purchases in base case ..............................................................14

Figure 5. Allowance sales in base case.........................................................................14

Figure 6. Change in base-case levelized electricity costs when conservation is limited to nine states.

Figure 7. Increases in base-case emissions when conservation occurs in all states. (States where emissions decreased are blank; see Figure 8 for amount of emission decrease. Emissions for utilities mapped to Arkansas did not change)

Figure 8. Decreases in base-case emissions when conservation occurs in all states. (States where emissions increased are blank; see Figure 7 for amount of emission increase. Emissions for utilities mapped to Arkansas did not change).

Figure 9. Change in base-case levelized costs when conservation occurs in all states.

\section{LIST OF TABLES}

Table 1. Expansion and compliance options represented in the model ............8 



\section{SUMMARY}

The 1990 Clean Air Act Amendments affect electric utilities in numerous ways. The feature that probably has received the greatest attention is the provision to let utilities trade emissions of sulfur dioxide $\left(\mathrm{SO}_{2}\right)$, while at the same time requiring them to reduce $\mathrm{SO}_{2}$ emissions in 2000 by an aggregate $43 \%$. The emission trading system was welcomed by many as a way of reducing the cost of reducing emissions, by providing greater flexibility than past approaches.

The required reduction in emissions requires that utilities reconsider their resource plans, to meet demand for service and limits on emissions at least cost. The emission trading system adds new options to resource and compliance planning, including the possibility of purchasing emission allowances, and the possibility of reducing emissions by more than required and selling the allowances not needed for compliance. Determining the value of these options requires some estimate of how much an allowance would cost to buy or earn when sold. The future market price of an allowance is highly uncertain, and estimates of future prices have decreased substantially since the Amendments were enacted, from roughly $\$ 500$ per ton of $\mathrm{SO}_{2}$ to around $\$ 200$.

The system for trading allowances contains some incentives for utilities to reduce the rate at which their demand for electricity increases, by placing a permanent cap on total $\mathrm{SO}_{2}$ emissions rather than by setting a maximum rate of emissions per kilowatt-hour ( $\mathrm{kWh}$ ). Once utilities meet the cap, using fossil fuels to meet an increase in demand will require offsetting reductions in emissions from some other existing generating facility. Reducing future demand will delay the need for these additional emission controls. However, reducing future demand also would reduce the future demand for and value of emissions allowances, further increasing the uncertainty in the integrated resource planning (IRP) process of determining whether to buy or sell allowances. Moreover, the allowance prices faced by one utility can be influenced by the compliance and energy efficiency decisions made by other utilities.

This report examines some of the potential interactions between trading emissions and increasing end-use energy efficiency. The analysis focuses on emission trading in the second phase of the trading program, which begins in 2000. The aggregate effects, calculated by an emission compliance and trading model, turn out to be rather small. Aggressive improvement of end-use efficiency by all utilities might reduce allowance prices by $\$ 22 /$ ton (1990 dollars), which is small compared to the reduction that has occurred in the estimates of future allowance prices and when compared to the roughly $\$ 400 /$ ton price we estimate as a base case. However, 
the changes in the allowance market that result are large enough to affect some compliance decisions. If utilities in only a few states improve end-use efficiency aggressively, their actions may not have a large effect on the price of an allowance, but they could alter the demand for allowances and thereby the compliance decisions of utilities in other states.

The analysis shows how improving electricity end-use efficiency in some states can cause smaller emission reductions in other states, relative to what would have happened without the improvements. Such a result, while not surprising given the theory behind the emission trading system, is upsetting to people who view emissions, environmental protection, and energy efficiency in moral rather than strictly economic terms.

Analysis of compliance and resource decisions for two utilities shows that the cost of an allowance can have large effects on utility compliance plans, at least for some utilities. Increased end-use efficiency has a greater effect on expansion plans than on compliance plans, although this result reflects some limitations of the model.

These results assume that the allowance trading market will function as its designers intended. There are several reasons to expect that the market will not function this way, at least in its early stages. Perhaps the most important of these is the complexity and lead time required to establish regulations and institutions to enable emission trading to work. Other reasons include uncertainty about future allowance prices, generating technologies, and possible additional environmental protection programs. For all of these reasons, fewer allowances are likely to be traded than originally anticipated when the market was designed, and the interactions between allowance trading and energy efficiency are likely to be more limited than the model estimates.

Finally, the emission trading system contains some incentives that provide additional allowances to utilities that practice effective IRP. These incentives have had relatively small effects, when measured by the number of allowances earned, but their long-term effect on IRP and efficiency improvement may be greater.

The report identifies several areas needing additional research. The most important of these are the problem of integrating local environmental concerns into a national emission trading system, and the need to better understand public acceptance or rejection of some of the concepts and results of emission trading.

In summary, the emission trading system has increased the complexity of IRP, while at the same time providing direct and indirect incentives to increase its use. 


\section{LIST OF ACRONYMS}

$\begin{array}{ll}\text { ARAC } & \text { Acid Rain Advisory Committee } \\ \text { EIA } & \text { Energy Information Administration } \\ \text { EPA } & \text { Environmental Protection Agency } \\ \text { IRP } & \text { Integrated Resource Planning } \\ \text { IRS } & \text { Internal Revenue Service } \\ \text { NAPAP } & \text { National Acid Precipitation Assessment Program }\end{array}$




\section{INTRODUCTION}

Title IV of the 1990 Clean Air Act Amendments (P.L. 101-549) requires electric utilities to reduce emissions of precursors of acid precipitation, specifically sulfur dioxide $\left(\mathrm{SO}_{2}\right)$ and oxides of nitrogen $\left(\mathrm{NO}_{x}\right)$, starting at 261 generating units in 1995 and covering most fossil-fired units in 2000. The Amendments take a conventional command-and-control approach to reducing $\mathrm{NO}_{\mathrm{x}}$, but they established a marketbased regulatory system to reduce $\mathrm{SO}_{2}$. Under this system, utilities that own fossilfired power plants in the conterminous 48 states and the District of Columbia are granted the right, in the form of "allowances," to emit a specified number of tons of $\mathrm{SO}_{2}$. A utility that wants to do so may reduce emissions more than required by the number of allowances it receives and then either sell its excess allowances to other utilities or bank them for future use. Alternatively, it can buy additional allowances from other utilities who may wish to sell, and emit more than its original allocation would have permitted, provided that it holds enough allowances from some source to cover emissions.

From each utility's perspective, the future cost and availability of allowances are unknown, and this introduces additional uncertainties into utility planning. This uncertainty could affect a utility's decisions on how to comply with the Amendments, but it also could affect its decisions to build new capacity or to increase energy efficiency among its customers.

At the same time, the Amendments and a number of more recent actions by utilities, states, and the federal government all promote increases in energy efficiency. These actions include the Environmental Protection Agency's Green Lights program to encourage energy-efficient lighting; decisions by several utilities to reduce projected emissions of greenhouse gases; and actions by several states, some prompted by the Amendments, to promote integrated resource planning (IRP) which gives demand-side measures equal consideration to supply-side measures in utility planing. If these measures yield significant reductions in projected demand for electricity, then they should affect the cost and availability of allowances, increasing the uncertainty in utility planning.

The research described here attempts to estimate how large these interacting effects might be and how they might affect the choices that utilities make when complying with Title IV of the Amendments. We do so using a model that was designed to estimate what options electric utilities might choose in complying with Title IV, and what effects compliance would have on electricity costs (Hillsman and Alvic 1991). The model assumes that the allowance trading system would work as smoothly as the economic theory on which the system is based. Actual compliance 
decisions announced to date have been somewhat different from what theory and the model project. We discuss some of the reasons for these differences and the likely effects these differences may have on the interaction between allowance trading and energy efficiency. 


\section{AN OVERVIEW OF THE $\mathrm{SO}_{2}$ EMISSION TRADING SYSTEM}

\section{EMISSION TRADING IN PRINCIPLE}

Title IV takes effect in two phases, one in 1995 and one in 2000; the provisions for the two phases differ slightly, and for simplicity we discuss only the second phase here. The Title sets a national limit of 8.95 million tons of $\mathrm{SO}_{2}$ emissions per year from electric utilities in 2000 and 8.9 million in 2010. This is approximately a $43 \%$ decrease from the 15.7 million tons emitted in 1990 (EPA 1991), and it is roughly equivalent to setting a national emission standard of $1.2 \mathrm{lb} . \mathrm{SO}_{2} /$ million Btu heat input for coal-fired power plants using levels of fuel use and generation from the mid 1980s. Title IV uses a lengthy set of rules to allocate the allowances in 2000 to the owners of fossil-fired generating units in the conterminous 48 states and the District of Columbia. The Title then requires each generating unit to emit no more tons of $\mathrm{SO}_{2}$ than it has allowances. The owner of a generating unit then has several choices: (1) reduce emissions from the unit to the level required; (2) reduce emissions to a level below the number of allowances and either save the excess allowances or sell them; (3) make smaller emission reductions and purchase allowances from others to make up the difference between its own allowances and its emissions. An owner of multiple units is free to transfer allowances among them as long as total emissions do not exceed the number of allowances in hand.

The cost of reducing emissions from existing generating units is highly sitespecific and depends upon the type and arrangement of plant equipment, the amount of land available (for storing and blending low-sulfur coal or for disposing of scrubber wastes), the delivered costs of different types of coals, the present emission rate and the amount by which emissions are to be reduced. The law presumes that utilities that can reduce emissions relatively cheaply will do so and sell excess allowances to those that have relatively high emission control costs. The allowance price would be high enough to cover the cost of making extra emission reductions at low-cost units, but it would be below the cost required to reduce emissions at units with high control costs. Utilities with high control costs and those with low control costs would find it advantageous to trade at such a price.

To provide a numerical context to the discussion, emission rates range from well under .01 pounds $\mathrm{SO}_{2} / \mathrm{kWh}$ at the cleanest coal-fired plants to nearly .06 pounds at the dirtiest. Shortly after the 1990 Amendments were enacted, allowance prices were expected to be in the vicinity of $\$ 500 /$ ton, or from under $\$ .0025$ to $\$ .015 / \mathrm{kWh}$ depending on the emission rate. More recent estimates of allowance prices have been in the neighborhood of $\$ 200 /$ ton, or from under $\$ .001$ to $.006 / \mathrm{kWh}$. 
In contrast, the average fuel cost for electricity in the Midwest in 1990 was $\$ .0155$ (EIA 1993)

In theory the trading system would produce the lowest possible cost of reducing emissions to the level set by the number of allowances. Furthermore, such a system would provide incentives to control only to the amount required by the total number of allowances, and not to spend unnecessarily to reduce emissions more than the Title requires. Underlying the expected efficiency of the emission trading system are several other assumptions: there must be sufficient information for buyers and sellers to determine an appropriate allowance price; utilities will buy and sell allowances when it is advantageous for them to do so; the market must be free from manipulation; and the value of emission reductions must be the same at all emitting locations.

\section{A SHIFT FROM REGULATING RATES TO CAPPING EMISSIONS}

Although the emission trading system is regarded as perhaps the most innovative feature of the 1990 Amendments, the establishment of a national cap on emissions may prove to be at least as significant.

Prior to passage of the 1990 Amendments, limits were set on $\mathrm{SO}_{2}$ emission rates but not on the quantity of $\mathrm{SO}_{2}$ that could be emitted. For example, previous legislation required new utility emission sources to meet an emission rate standard of no more than $1.2 \mathrm{lb} . \mathrm{SO}_{2} /$ million Btu heat input. Most bills introduced to amend the Clean Air Act prior to passage of the Amendments would have established similar kinds of limits on emission rates on existing sources as well. Indeed, the rules Title IV uses to allocate allowances among existing coal-fired generating units are equivalent to assuming a $1.2 \mathrm{lb} . \mathrm{SO}_{2} /$ million Btu emission rate, although the actual rate will be lower because the Title requires pro rata reductions of any excess allocation to yield a total of 8.9 million tons. Rate and quantity standards have some fundamentally different implications for electric utilities and for energy efficiency.

First, rate standards provide very limited incentive for a utility to improve the efficiency with which electricity is generated or used. Holding fuel type and demand for electricity constant, if a utility operates plants with high heat rates (Btu/kWh generated), or if it has high transmission and distribution losses, these inefficiencies have no effect on the $\mathrm{SO}_{2}$ emission rate. The utility can make up the losses or increase its generation using additional equipment operating at the allowable emission rate. Adding equipment may increase costs, but the only incentive that an emission rate limit provides to improve supply efficiency is through the (presumably) higher costs of adding equipment that meets the allowable rate. Some "clean coal" technologies have the potential to emit $\mathrm{SO}_{2}$ at rates well within those considered as alternative amendments to the Clean Air Act, and to do so at costs equivalent to or lower than those of conventional coal-fired technology. Thus, these technologies could have offset even the very limited incentive that emission rate limits provide for improving supply-side efficiency. 
The same argument is true on the demand side. Emission rate limits would increase emission control costs and, therefore, electricity prices. This would provide some incentive to improve the efficiency of electricity use. However, utilities could meet additional demand using standard equipment operating at or below the compliance rate.

In the short run, limiting emission rates could reduce aggregate amounts of $\mathrm{SO}_{2}$ as utilities retrofit existing plants with equipment to meet the allowable rate. Emissions of $\mathrm{SO}_{2}$ by utilities declined from nearly 18.3 million tons in the mid 1970s (prior to the 1977 Clean Air Act Amendments) to 15.1 million tons in 1987 (EPA 1991). However, in the long run aggregate emissions of $\mathrm{SO}_{2}$ could increase as new plants are added to meet growth in demand for electricity and continuing inefficiencies in generation, transmission, and use. Again, this happened, as emissions increased from 15.1 million tons in 1987 to 15.4 million tons in 1989 and 15.7 million tons in 1990 (EPA 1991), as retrofitting was completed, retirement of existing capacity was slowed, and demand for electricity increased. The NAPAP assessment (1991) projected that, in the long term, all existing power plants not required to retrofit would be replaced by new ones subject to the rate limit. This replacement would lead to lower emissions than at present. Long-term growth in demand, met by burning sulfur-bearing fossil fuels, would eventually require some increase in aggregate emissions above whatever minimum might be achieved under the standard (Figure 1), although improvements in technology might offset or delay it.

Imposing a limit or cap on aggregate emissions changes the situation markedly. Holding fuel type and demand for electricity constant, a high heat rate or high losses in transmission and distribution means a larger quantity emissions per $\mathrm{kWh}$ delivered to the customer. Improving the heat rate or reducing the losses reduces the tonnage. Improving end-use efficiency (more service with the same or fewer $\mathrm{kWh}$ and, therefore, the same or fewer emissions) also reduces tonnage. Furthermore, once the utility system is operating at the aggregate limit, a utility that wants to increase its emissions to meet additional demand must obtain a reduction in emissions from some other utility (Figure 1). As in the case of the emission rate limit, improvements in supply technologies could allow utilities to meet additional demand at lower costs and lower emission rates, thereby requiring smaller offsets than would the use of conventional technology. It is even conceivable that improvements in supply technologies, or utility behavior not anticipated in the design of the emission trading system, could reduce aggregate emissions to levels below the national limit. Nevertheless, the aggregate limit of 8.9 million tons per year ensures that emissions will not exceed the limit even if demand increases.

It should be noted that it was not necessary to impose a cap on aggregate emissions in order to create a trading system. It is possible, although less straightforward, to construct an emission trading system that operates within an aggregate emission rate limit. For example, a utility that emits at a rate higher than a target rate (e.g., $1.2 \mathrm{lb} . \mathrm{SO}_{2} /$ million Btu) could be required to purchase rights to do 


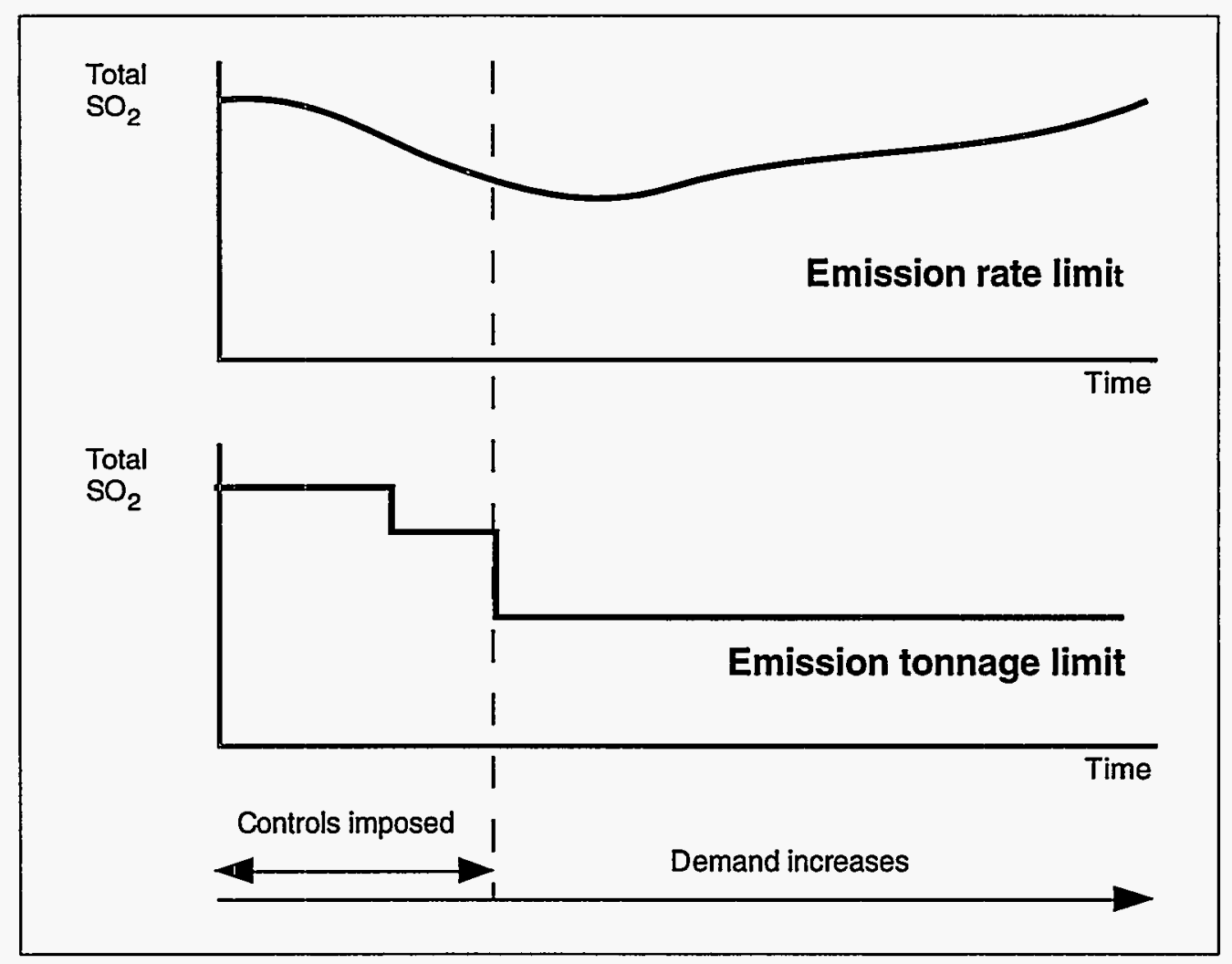

Figure 1. Comparison of rate and tonnage limits on emissions as demand increases.

so from a utility that emits at less than the target rate. Aggregate emissions could still increase under such a system as generation increases. By placing the cap on aggregate emissions, Title IV creates incentives for end-use efficiency even in the absence of some of its other features. 


\section{ESTIMATING HOW ENERGY EFFICIENCY AND EMISSION TRADING INTERACT}

A utility can compare the cost of reducing emissions by improving supply or end-use efficiency with the cost of adding scrubbers, switching to cleaner fuels, entering the allowance market to buy or sell, replacing existing capacity with new cleaner capacity, or adding capacity such as renewables or nuclear that do not emit $\mathrm{SO}_{2}$. These are the kinds of options compared in IRP (Hirst, Goldman and Hopkins 1990). We developed a model to make such comparisons, considering the entire utility system of the conterminous 48 states in order to represent the allowance trading market. We ran the model using three simple scenarios to examine how improving end-use efficiency might interact with the allowance trading system and with compliance decisions chosen by utilities. The model originally was designed to be run for an individual utility, given an assumption about the market price of an allowance, to estimate how different prices might affect its compliance decisions. We therefore ran the model for two different utilities to examine compliance at a finer scale.

\section{MAJOR FEATURES AND ASSUMPTIONS OF THE MODEL}

The model is a large linear program (Hillsman and Alvic 1991; Hillsman and Alvic 1994). The model represents each utility and each fossil-fired generating unit individually; nonfossil units are aggregated to the level of plants or, in the case of hydroelectric plants, across all of a utility's hydro units. Each generating unit has an assumed maximum capacity factor which limits generation from the unit; these values reflect historical performance of the unit. The model uses as its base year 1991, and it plans for two compliance years: 1995 when Phase I of Title IV takes effect, and 2000 when Phase II takes effect. Each utility must meet a projected demand for kilowatt-hours in each compliance year. To do so, it may operate its existing generating units, retire them, or build new ones in any combination; it also may undertake efforts to improve end-use efficiency. For each existing coal-fired unit the utility may add $\mathrm{SO}_{2}$ emissions controls, switch to low-sulfur coal, add $\mathrm{NO}_{x}$ controls (to comply with other requirements of the Amendments), retire the unit early, or extend its useful lifetime. A utility may reduce emissions from a generating unit in Phase I to comply with Phase II. A utility may add generating capacity using several fossil fuel options, and it may use conservation to reduce projected demand. Each unit and compliance option has an associated generation and emission tonnage; the generation from all of a utility's units must equal its demand, and the $\mathrm{SO}_{2}$ emissions summed over all utilities must not exceed the 8.9 million ton limit set for the nation. In addition, the model can limit the availability 
Table 1. Expansion and compliance options represented in the model

Present

Technology

Technologies allowed in Time Period 1

$\begin{array}{cccccc}\text { Same Retire } & \begin{array}{c}\text { Scrubber/ } \\ \mathrm{NO}_{\mathrm{x}} \\ \text { control }\end{array} & \text { Scrubber } & \mathrm{NO}_{\mathrm{x}} & \mathrm{Low} & \text { control } \\ & & & \begin{array}{c}\text { sulfur } \\ \text { coal }\end{array} & \begin{array}{c}\text { sulfur } \\ \text { coal/ } / \mathrm{NO}_{\mathrm{x}}\end{array}\end{array}$

\begin{tabular}{|c|c|c|c|c|c|c|}
\hline High-sulfur coal steam & $\mathrm{x}$ & $\mathrm{x}$ & $x$ & $x$ & $\mathrm{x}$ & $x$ \\
\hline w/existing scrubber & $x$ & $x$ & $x$ & & & \\
\hline $\mathrm{w} / \mathrm{NO}_{\mathrm{x}}$ control & $x$ & $x$ & $x$ & & & \\
\hline $\mathrm{w} /$ scrubber $/ \mathrm{NO}_{\mathrm{x}}$ control & $x$ & $\mathrm{x}$ & & & & \\
\hline Low-sulfur coal steam & $x$ & $\mathrm{x}$ & $x$ & $x$ & $x$ & \\
\hline Lignite steam & $\mathrm{x}$ & $x$ & $\ddot{x}$ & $x$ & $x$ & \\
\hline $\mathrm{Oil}^{*}$ & $x$ & $x$ & & & & \\
\hline Gas* & $x$ & $\mathrm{x}$ & & & & \\
\hline Nuclear & $x$ & $x$ & & & & \\
\hline Hydro & $x$ & & & & & \\
\hline
\end{tabular}

Technology in

Period 1

Technologies allowed in Period 2

\begin{tabular}{ccccc} 
Same Retire & $\begin{array}{c}\text { Scrubber/ } \\
\mathrm{NO}_{x} \\
\text { control }\end{array}$ & Scrubber & $\mathrm{NO}_{x}$ & Low \\
control & $\begin{array}{c}\text { sulfur } \\
\text { coal }\end{array}$ & $\begin{array}{c}\text { Low- } \\
\text { sulfur } \\
\text { coal/ } / \mathrm{NO}_{\mathbf{x}}\end{array}$ \\
\hline
\end{tabular}

\begin{tabular}{|c|c|c|c|c|c|c|}
\hline High-sulfur coal steam & $\mathrm{x}$ & $x$ & $x$ & $x$ & $x$ & $x$ \\
\hline w/existing scrubber & $\mathrm{x}$ & $x$ & $x$ & & & \\
\hline $\mathrm{w} /$ added scrubber** & $x$ & & $x$ & & & \\
\hline $\mathrm{w} / \mathrm{NO}_{\mathrm{x}}$ control & $\mathrm{x}$ & $x$ & $x$ & & & \\
\hline w/scrubber $/ \mathrm{NO}_{x}$ control & $x$ & $x$ & & & & \\
\hline Low-sulfur coal steam & $x$ & $x$ & $x$ & $x$ & $x$ & \\
\hline Lignite steam & $\mathrm{x}$ & $x$ & $x$ & $\mathrm{X}$ & $x$ & \\
\hline Oil* & $\mathrm{x}$ & $x$ & & & & \\
\hline Gas* & $\mathrm{x}$ & $x$ & & & & \\
\hline Nuclear & $\mathrm{x}$ & $x$ & & & & \\
\hline Hydro & $\mathrm{x}$ & & & & & \\
\hline Retired & $x$ & & & & & \\
\hline
\end{tabular}

Generation from new units

Period

Clean coal technology

New low-sulfur coal capacity

New high-sulfur coal capacity

New gas capacity

Improve end-use efficiency

*Steam or combined cycle

**Scrubber added by model for period 1 both, period 2 only, or neither

both or neither

both or neither

both or neither

both or neither 
of selected fuels, such as Appalachian low-sulfur coal or natural gas, to reflect expected scarcities or to match scenarios prepared by other organizations such as the Energy Information Administration (EIA).

The model seeks the set of generation, plant construction, and compliance options that meets demand and emission requirements at the minimum cost. The cost minimization feature of the model is consistent both with the objectives of IRP and with the intent of the $\mathrm{SO}_{2}$ allowance trading system. The model tracks each unit, its generation, its compliance options, and its emissions, along with the amount of new power plant construction and reductions in electricity use undertaken by each utility. Emission trading is calculated from the model results by comparing each utility's allowance allocation with its emissions. The linear program calculates a shadow price for each constraint. The shadow price for the constraint that limits the number of allowances is the value to the utility system of having an additional allowance available, and it is an estimate of the cost of an allowance which can be used to adjust utility costs for the effects of trading allowances.

The modeling system uses levelized costs for all compliance and expansion options. Levelizing accounts for long-term inflation and real price escalation in the costs of fuel and the costs constructing new facilities. Costs reported by the modeling system only include those for fuel; operations and maintenance; and additional capital expenditures for generating capacity, compliance with the Amendments, and improving end-use efficiency. Reporting electricity prices would require the use of additional information on each utility's previous capital expenditures. However, this information was not available in a form that would allow its use in the modeling system.

Where compliance and expansion options require substantial lead times for construction, the modeling system calculates levelized costs for these options using an assumed construction schedule, and the option is assumed to begin operating in the compliance year for which it is required.

Because it represents and tracks individual generating units, the model requires data for individual units. The cost and amount of electricity generated by each unit is reported to EIA or can be closely estimated, as can key variables such as heat rate (efficiency of the unit); Hillsman and Alvic (1994) describe data sources in detail. The unit-specific cost of adding emission controls or switching fuels, however, was not available for the entire country. For emission control costs, we use national estimates. These are adjusted for site-specific circumstances at a few plants based on a study commissioned by the Environmental Protection Agency (Energy Ventures Analysis 1986). To estimate costs of coal switching, we use a simple model to estimate costs of production in different mining districts, a more complex model to estimate shipping distances from mines to power plants, and aggregated estimates of coal shipping costs (Hillsman and Alvic 1994). 
The model's original design did not include end-use energy efficiency (Hillsman and Alvic 1991). However, to a limited extent we can simulate end-use efficiency measures by allowing each utility to use small amounts of a non-emitting supply technology with costs and availability comparable to end-use efficiency measures now being promoted by utilities. Because the model minimizes cost, and because efficiency substitutes for increased supplies without emitting controlled pollutants, the model will let utilities reduce end-use consumption as much as the user allows, unless the cost of improving end-use efficiency exceeds the cost of other options. Hence it is necessary to limit the amount of efficiency that each utility can implement. If a conservation supply curve were available for an individual utility, the model could be modified easily to incorporate it.

The model's original purpose was limited to analyzing compliance decisions for existing coal-fired power plants, and therefore its design did not include natural gas as an option for capacity expansion. For this analysis, we added natural gas as an expansion option because it appears to be a preferred choice among utilities and therefore more appropriate than coal alone for comparison to end-use efficiency improvements. Because of its emissions and sometimes cost advantages compared to coal, it is necessary to limit the availability of natural gas in the model to quantities that EIA (1991) projected for each region of the nation, in order to keep gas from displacing unrealistic amounts of coal-fired capacity. The model uses regional costs for natural gas, taken from the same EIA projection.

Finally, the model can be used to examine some unanticipated behaviors by defining its input data to include announced compliance decisions or other announced actions by utilities or other parties; by running it with restricted options or for restricted groups of utilities; or by incorporating within it unanticipated features of the emission trading market such as high commissions on allowance trades.

\section{SCENARIO ASSUMPTIONS}

We compare two scenarios with a base case that assumes implementation of Title IV under a projected 1.6\% annual growth in demand for kilowatt-hours through 2000 when the Title's second phase takes effect. The demand growth rate is calculated from an EIA reference case (1991) and probably includes some efforts to improve end-use efficiency, although the document that reported the reference case did not discuss them. In modeling the base case, we assumed that all increases in demand would be met using new coal- or gas-fired generating units of conventional technology. The reference case projected the use and price of natural gas for ten regions of the country, and our base case uses these to limit the availability of natural gas and set its price for the analysis. Coal prices and availability are estimated within the modeling system, as data for the linear program, based on transportation costs and historic production costs. Capacity expansion is subject to the emission cap. 
Our first scenario assumes that aggressive efforts to improve end-use efficiency occur only in nine states: California, Wisconsin, New York, and the six New England states. These states are among those have taken the lead in encouraging their utilities to promote end-use efficiency (Hirst 1993). Thus, this scenario has some similarity to what might have been expected from the perspective of the early 1990s, assuming that other states might not have become more active in the past few years. We assumed that each utility in these states could implement conservation measures by 1995 that could reduce projected demand for kilowatthours by up to $5 \%$ of their 1985 generation, that the reduction would continue through 2000, and that no additional demand-reduction measures would be implemented after 1995. On average, these assumptions yield a reduction in 1995's projected demand of just under $4.1 \%$ and, because of continuing demand growth, a reduction of just over 3.8\% from demand projected for 2000 .

We assumed that the demand-reduction measures would be functionally equivalent to a baseload plant operating with a .65 capacity factor; and that the cost would be equivalent to $\$ 500 / \mathrm{kW}$ of capacity or approximately $\$ .02 / \mathrm{kWh}$ averaged over 5 years. The capacity cost, although higher than the cost of many efficiency improvements now being implemented in these states, is still less than the $\$ 1520$ $1600 / \mathrm{kW}$ assumed for new coal- and gas-fired steam plants. As noted above, the model will implement as much conservation as it is permitted as long as the cost is lower than that of the alternatives; we have confirmed this by running the model using a wide range of costs for the level of efficiency improvement assumed in the first scenario. Thus the choice of a cost for efficiency improvement is arbitrary within a large range. The implementation schedule we assumed for improving efficiency is aggressive, but it allows us to identify issues for further analysis.

Our second scenario assumed that aggressive efforts to improve end-use efficiency would be made in all states. Otherwise we used the same costs and assumptions as in the first conservation scenario.

We use maps to present a few results from the two scenarios, and interpreting the maps requires understanding the conventions used to prepare them. The building blocks of the model are generating units and utilities, not states. The model reports emissions and costs for existing and planned generating units, and these can be mapped either by the state in which they are located or by the utility that owns them. However, the model reports some values only by utility. These include: emissions and costs for additional generating capacity not now planned by utilities; allowance purchases and sales; and investments in end-use efficiency. It would be ideal to map all variables by utility, but we did not have available a map of utility service areas consistent with our utility data. Therefore, in order to map values involving variables that can be computed only at the utility level, we have assigned each utility to a state and assigned its utility-level variables to the state. Several large utility holding companies operate as integrated systems covering multiple states, and we have assigned each of these to one of the states in which it operates. This can cause some states to appear more or less sensitive than would be 
the case if these effects could allocated to states with greater precision, or if the maps could display utility service areas. In other cases a utility that builds new coal-fired capacity might well build it in a neighboring state, but the maps would show the emissions and costs attributed to the primary state that it serves.

Because the values reported and mapped by state below combine both statelevel and utility level data, we report only differences between scenarios rather than values projected for a specific scenario, except for a few national values which the model computes directly.

\section{FIRST SCENARIO-IMPROVE EFFICIENCY IN NINE STATES}

In the first scenario, utilities in the nine states where we assumed aggressive improvement of end-use efficiency made the maximum improvement we allowed, displacing new generation supplies and reducing emissions in all nine states (Figures 2 and 3). We expected this result given the relative costs and emissions we assumed for efficiency improvement and new power plants. Emissions also decreased by very small amounts in three states, and increased in three others. The following paragraphs discuss each of these groups in more detail.

First, the small decreases in emissions in Illinois, Indiana, and Nevada are a result of our limiting the availability of natural gas in the model. Increasing efficiency in California reduced the amount of natural gas needed to meet future demand, and this became available to a utility in Nevada. The model switched some of the future expansion for this utility from coal to natural gas. Increasing efficiency in Wisconsin had a similar effect on natural gas and emissions in Illinois and Indiana. In each of these states, emissions decrease by 1,000-4,000 tons $\mathrm{SO}_{2}$ per year. All three of the states were net sellers of allowances in the base case (Figures 4 and 5), and the additional natural gas allowed them to increase their allowance sales.

Emissions increased in Arizona, Texas, and Georgia. Arizona was a net purchaser of allowances in the base case, and purchased additional allowances in the conservation scenario. Texas, a net seller of allowances, sold just over 1,000 less; Texas appears to be a marginal or "swing" seller of allowances in the base case and lost some of its allowance market when efficiency improvements in other states made more allowances available. In the conservation scenario, the marginal or "swing" buyer of allowances is a utility in Georgia which owns a large plant burning high-sulfur coal. In the base case, the model partially scrubs one of the generating units at this plant, and the utility sells the excess allowances that result. In the scenario, this unit shifts from a supplier to a user of allowances, as the model removes the scrubber. This change shifts Georgia from being a net seller of 33,000 allowances to a net purchaser of 3,000. Approximately 1.123 million allowances are traded among all states in the base case, and about 18,000 fewer allowances are traded among all states in the first scenario. 


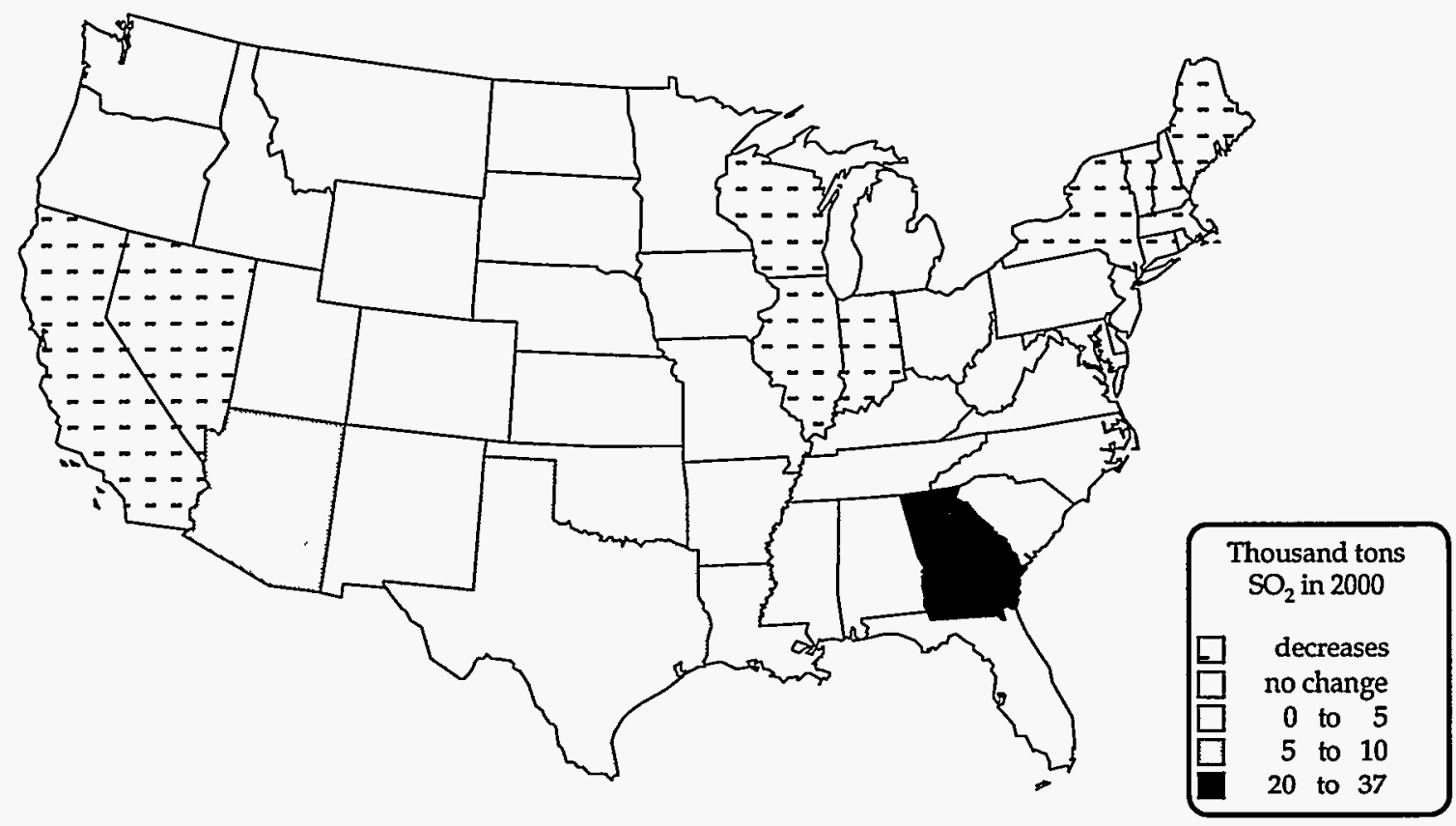

Figure 2. Increases in base-case emissions when conservation is limited to nine states. (States with no change in emissions are blank. States where emissions decreased have minus signs; see Figure 3 for amount of emission decrease).

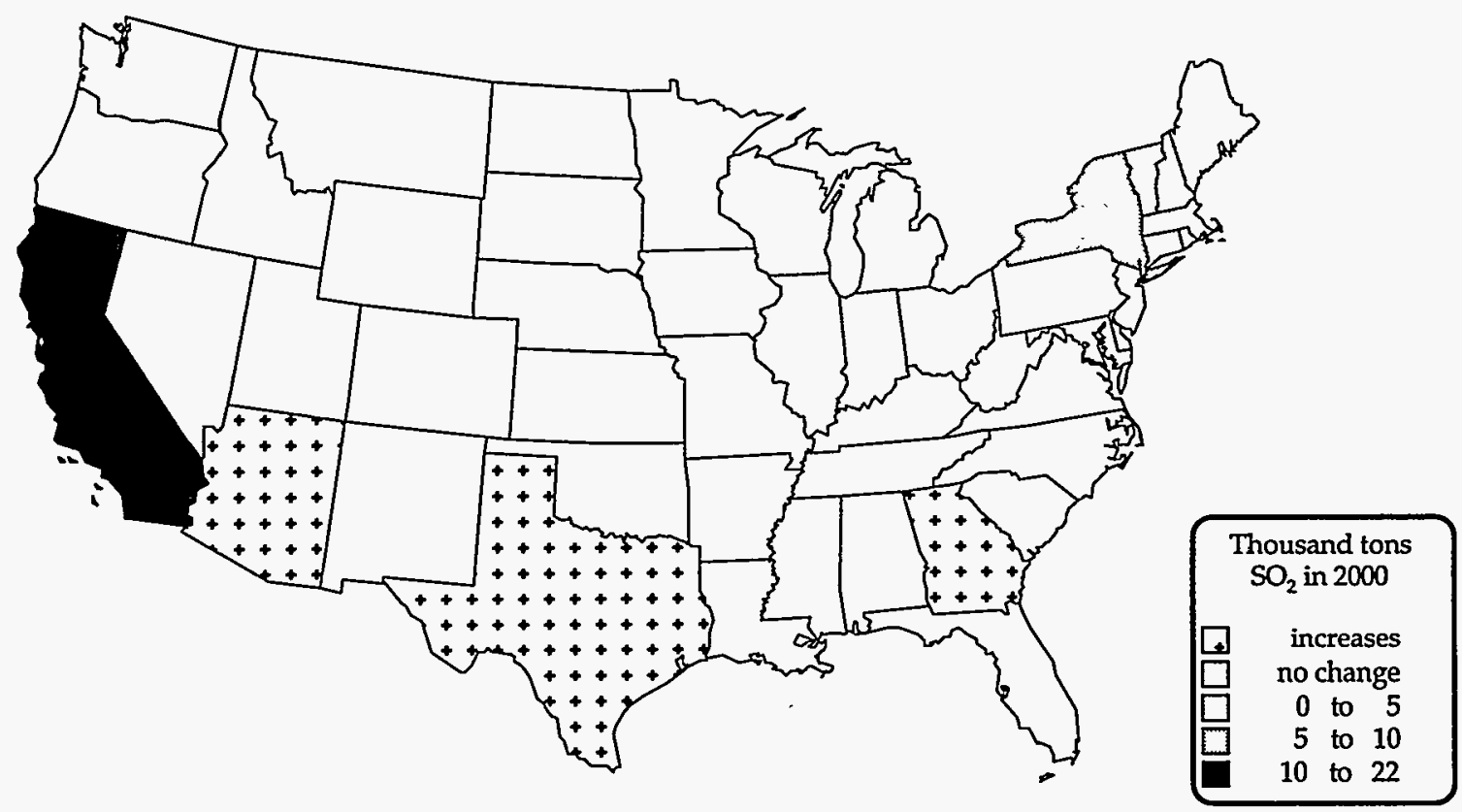

Figure 3. Decreases in base-case emissions when conservation is limited to nine states. (States with no change in emissions are blank. States where emissions increased have plus signs; see Figure 2 for amount of emission increase). 


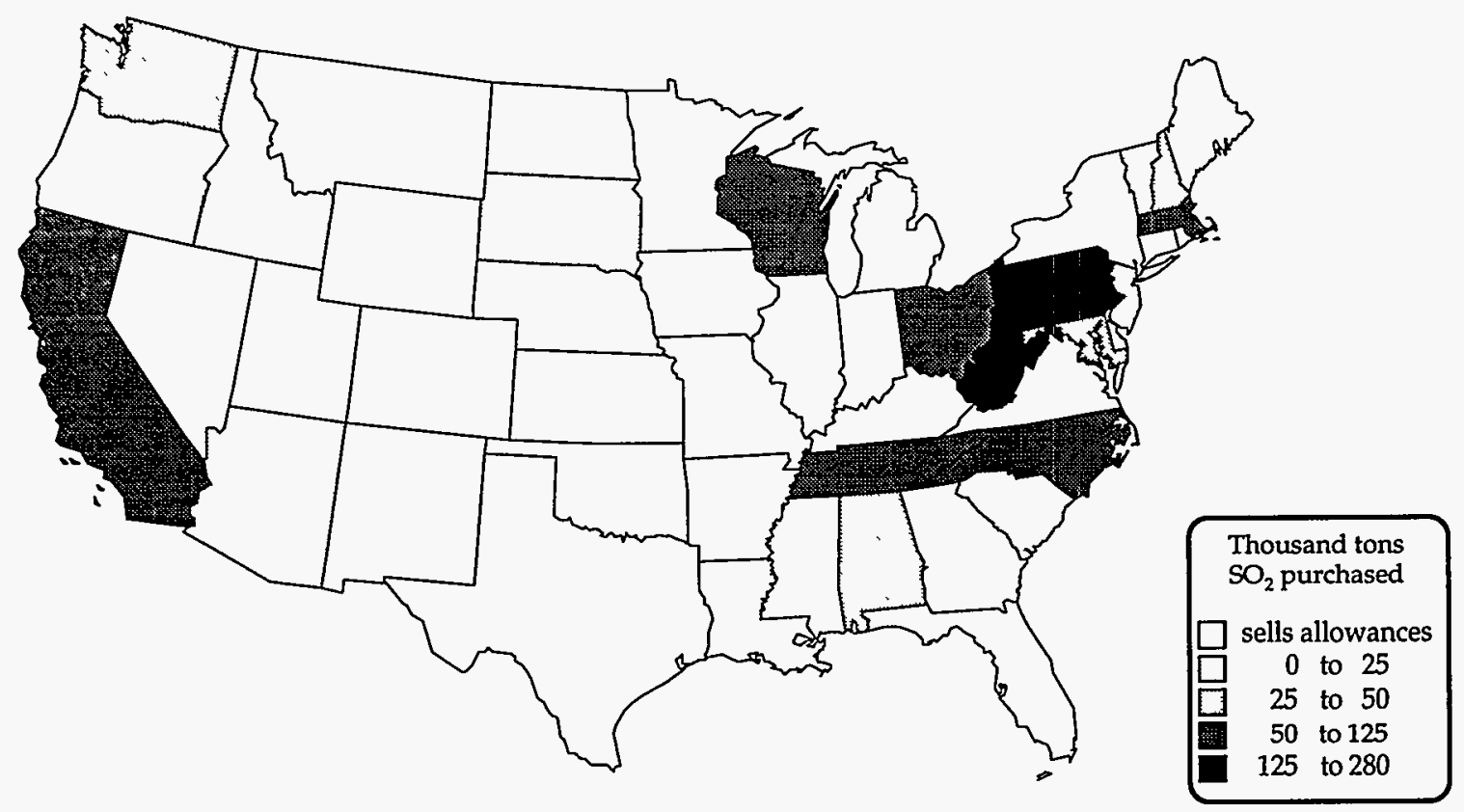

Figure 4. Allowance purchases in base case.

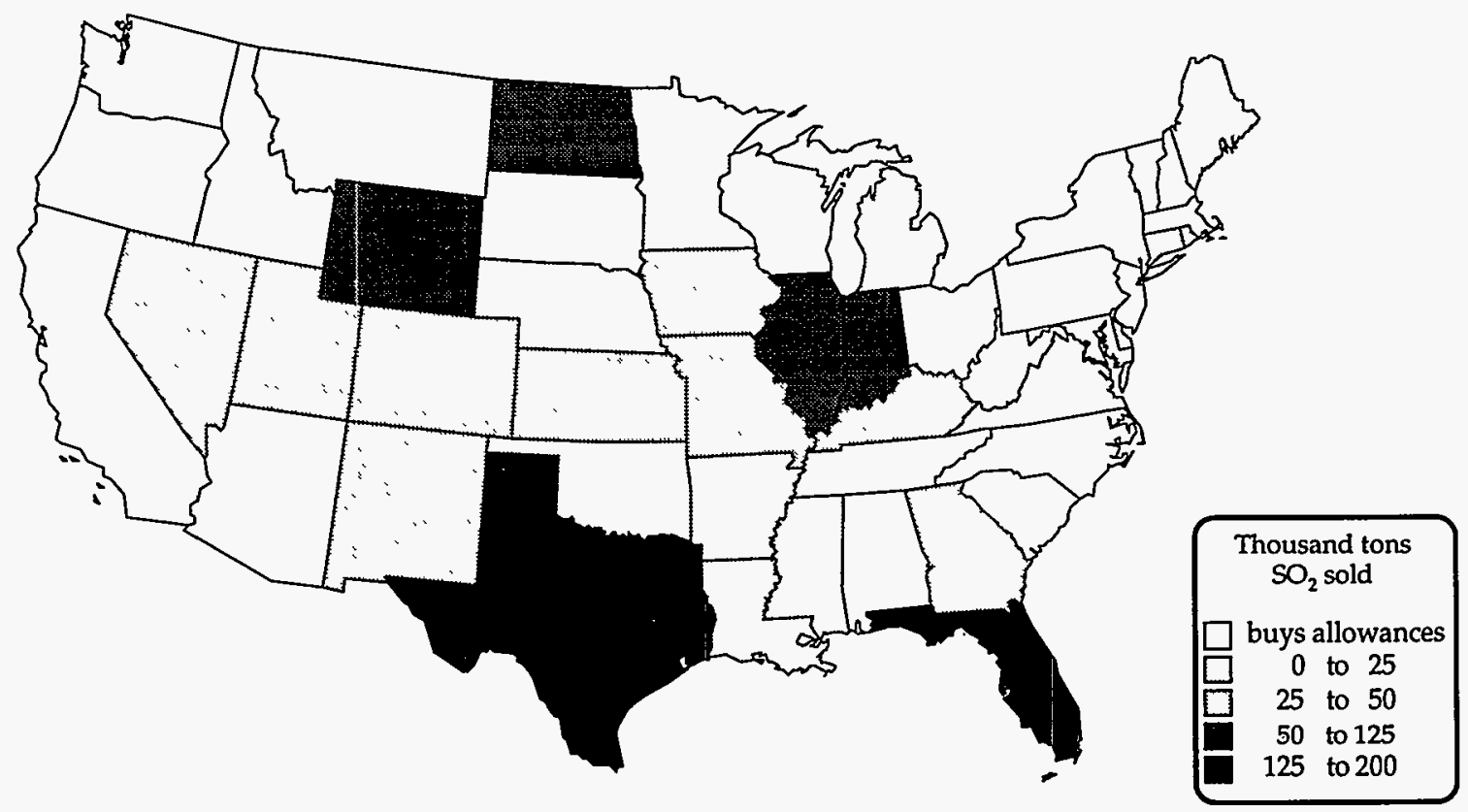

Figure 5. Allowance sales in base case. 
Results for utilities in the nine states that improved efficiency were diverse, although almost all of the effects of conservation showed up in expansion to meet new demand rather than in operations of existing equipment. Several small utilities in New England switched expansion from coal to gas, again reflecting the easing of the assumed limit on natural gas. Some utilities simply reduced the amount of coal-fired capacity added in the base case to meet additional demand, without switching this new capacity to gas. Others reduced the amount of gas-fired capacity added in the base case, again without substitution of other generation. Two utilities in California deferred retiring small gas-fired units and reduced expansion of coal-fired capacity; another cut back on use of an existing gas-fired unit and, again, reduced coal-fired expansion.

Intuition and a quick examination of the maps would suggest that the nine states that improved efficiency (Figure 3 ) are selling more allowances as a result, but the allowance trading market operates with more complexity than this. California, Massachusetts, New Hampshire, Vermont, and Wisconsin all bought allowances in our base case but bought fewer allowances after implementing conservation; together they reduced their demand for allowances by slightly more than 28,000 , with California accounting for three quarters of this. The other four states sold small numbers of allowances in the base case and sold slightly more in the efficiency scenario. The total number of additional allowances sold by these four states was just under 8,800, with New York selling most of these.

Improving efficiency in the nine states reduces nationwide generation by only $.59 \%$ in 2000 , and the resulting reduction in demand for allowances is too small to change the price of an allowance estimated in the base case. The scenario we prepared clearly is sensitive to assumptions about the availability of natural gas for generating to meet increased demand for electricity. However, given the allowance market, it is apparent that changes in conservation which affect demand for natural gas also can affect the regional pattern of $\mathrm{SO}_{2}$ emissions.

Given the cost assumptions, we expected the costs of providing service to decrease in the nine states where efficiency was improved, and they did (Figure 6). Averaged across the nation, the lower costs of efficiency improvements and the resulting decrease in costs to reduce emissions lowered costs by .33 mills $/ \mathrm{kWh}$ (expressed in levelized dollars as calculated by the model; approximately .23 mills in unlevelized 1990 dollars). In addition to the lower costs of efficiency improvements relative to expanded supply and compliance, allowance sales redistributed costs among utilities. Those utilities that sold additional allowances saw an increase in revenue from allowance sales, and those that bought fewer allowances saw reduced expenditures on allowances. Utilities in the 39 states that did not improve efficiency either sold fewer allowances or bought more, thereby earning less revenue or incurring higher expenses. However, these effects were outweighed by savings from reduced capacity expansion or from reduced compliance costs. In all of the latter cases, the effect of allowance trading on cost was .02-.03 mill $/ \mathrm{kWh}$ (levelized), which was lower than in any of the states where efficiency was improved. In the case of 


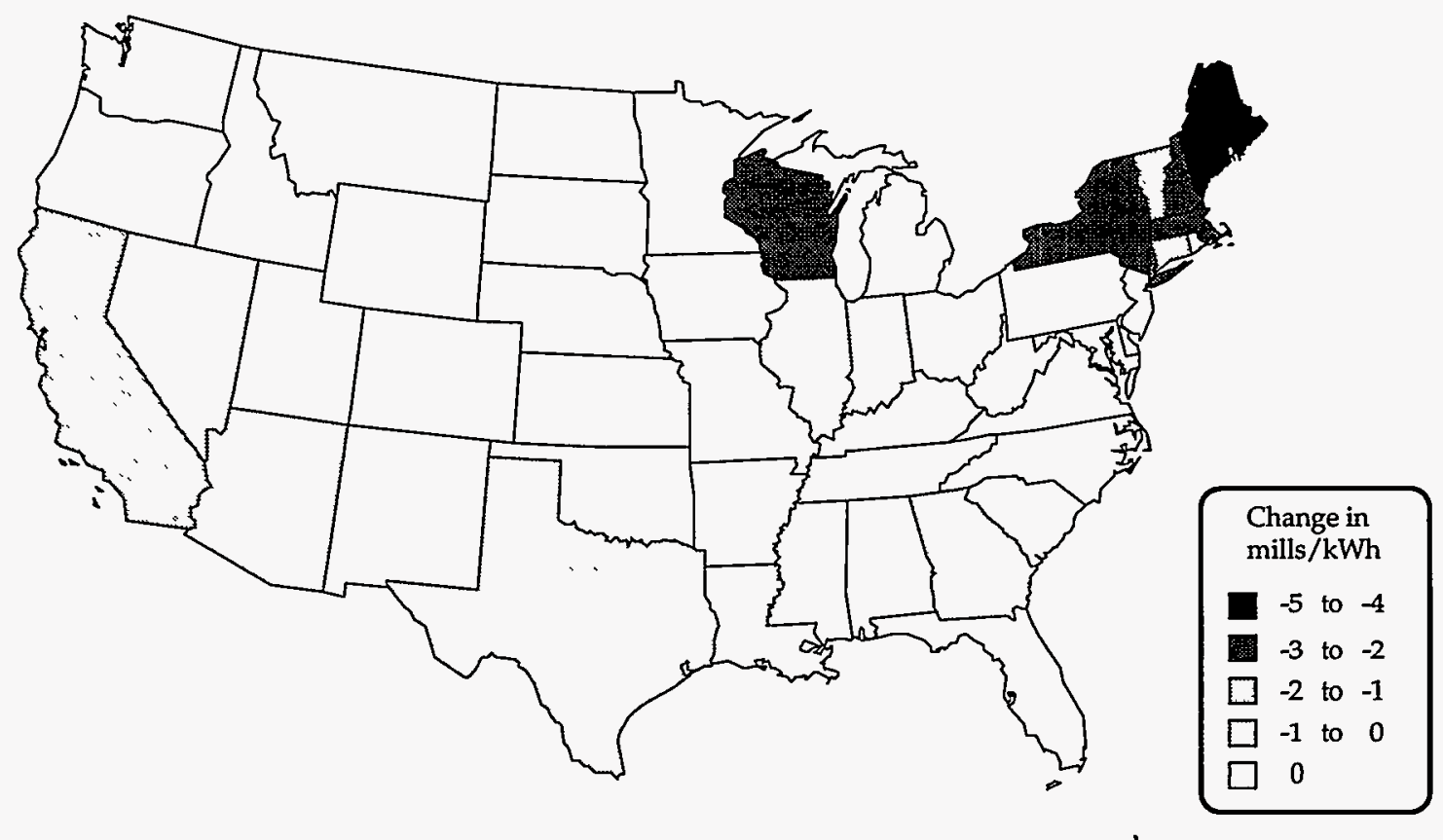

Figure 6. Change in base-case levelized electricity costs when conservation is limited to nine states.

Georgia, which shifted from being a seller to a buyer of allowances, the shift also reduced costs by only .03 mill $/ \mathrm{kWh}$, despite the large numbers of allowances involved. This result occurs because a utility in Georgia was the marginal buyer for the allowances released by efficiency improvements, because these allowances were applied to increase emissions from a single generating unit, and because the cost of an allowance did not change. As a result, the model estimates that the utility would be indifferent between purchasing allowances at this price and increasing its emission control investment, assuming allowances were available.

Thus, large improvements in efficiency in only a few states have the potential to affect compliance costs in other states through the allowance trading market. Moreover, to the extent that long-range transport of $\mathrm{SO}_{2}$ contributes to environmental degradation downwind (Ottinger et al 1990; NAPAP 1991), the allowance trading market can lead to perverse results such as an upwind state purchasing allowances that become available from improved efficiency in downwind states, thereby undoing some of the efforts by states downwind. The State of New York became concerned about the possibility of upwind purchases of allowances sold by one of its utilities. The state filed suit to require EPA to review such purchases (Lobsenz 1993a), and it has proposed regulating allowance trading among New York utilities.

When we ran the nine-state efficiency scenario using an earlier version of the model and older data, the results yielded a marginal buyer of allowances in Pennsylvania, upwind from the New York and New England states whose improvements in efficiency had made the allowances available. We therefore 
caution that the patterns of allowance trading and costs described and mapped here are merely illustrative, because we have used much generic (spatially uniform) data about projected demand, the cost of improving end-use efficiency, and the cost of compliance options - especially the costs of retrofitting scrubbers and building new plants. In addition, as we discuss in Chapter 4, the market for allowances may not work as smoothly as theory predicts. For these reasons, the actual patterns of buying and selling among states that would occur in these two scenarios are likely to differ from those shown here. The emission cap will reduce emissions of $\mathrm{SO}_{2}$ from recent levels, but the allowance trading market creates the potential for shifts in where the reductions occur.

\section{SECOND SCENARIO-IMPROVE EFFICIENCY IN ALL STATES}

When all states undertake aggressive measures to improve end-use efficiency, we estimate that allowance prices could decrease by $\$ 30 /$ ton from the base case (levelized dollars; approximately $\$ 22 /$ ton in unlevelized 1990 dollars). Emissions would increase in Pennsylvania, Georgia, Kentucky, Indiana, and Arizona, relative to both the base case (mapped in Figure 7) and the first scenario. Relative to the base case, Arizona and Pennsylvania increased their allowance purchases, Indiana and Pennsylvania reduced their allowance sales, and Georgia shifted from selling to buying. The situations of states that decreased their emissions (Figure 8) are much more diverse, and the marginal or "swing" buyers and sellers shift several times in the course of the model's adjustment from base case to nationwide efficiency improvement. Approximately 8,000 more allowances are traded in this scenario than in the base case.

All states showed a decrease in costs of meeting demand for electricity service (nationwide, a decrease of 1.7 levelized mills relative to the base case) except for Arkansas, whose .01-mill increase is an artifact of the mapping conventions described earlier. The mapping conventions also cause Mississippi and Alabama to show disproportionately large reductions in cost (Figure 9). Again, these results are intended to be illustrative.

Decreasing the assumed cost of efficiency improvement would further reduce the cost of electricity in this case, but by itself it would not affect the price of an allowance or the pattern of emissions. This is because the cost of efficiency improvement assumed in the model is already lower than the cost of other compliance options, so that the model is already improving efficiency as much as the assumption of a 5\% reduction in generation in 1995 allows. This result is characteristic for this kind of option in this kind of linear programming model, because the it is the least expensive option for meeting one constraint (demand) but places no requirements on others (such as the emission cap). Changing the scenario definition to use a different rate of adoption than a $5 \%$ reduction in generation in 1995 would affect both allowance price and emission patterns. 


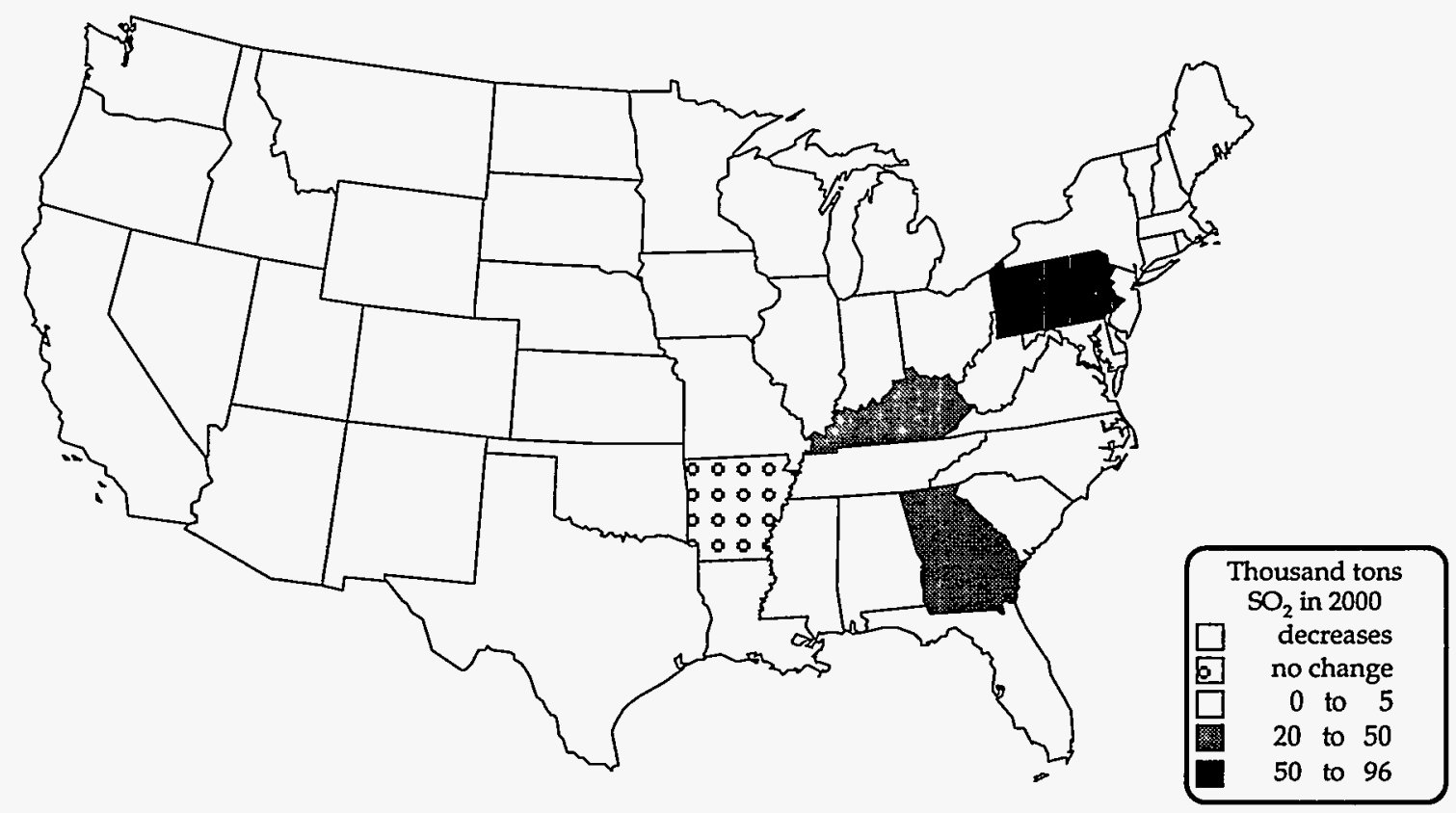

Figure 7. Increases in base-case emissions when conservation occurs in all states. (States where emissions decreased are blank; see Figure 8 for amount of emission decrease. Emissions for utilities mapped to Arkansas did not change).

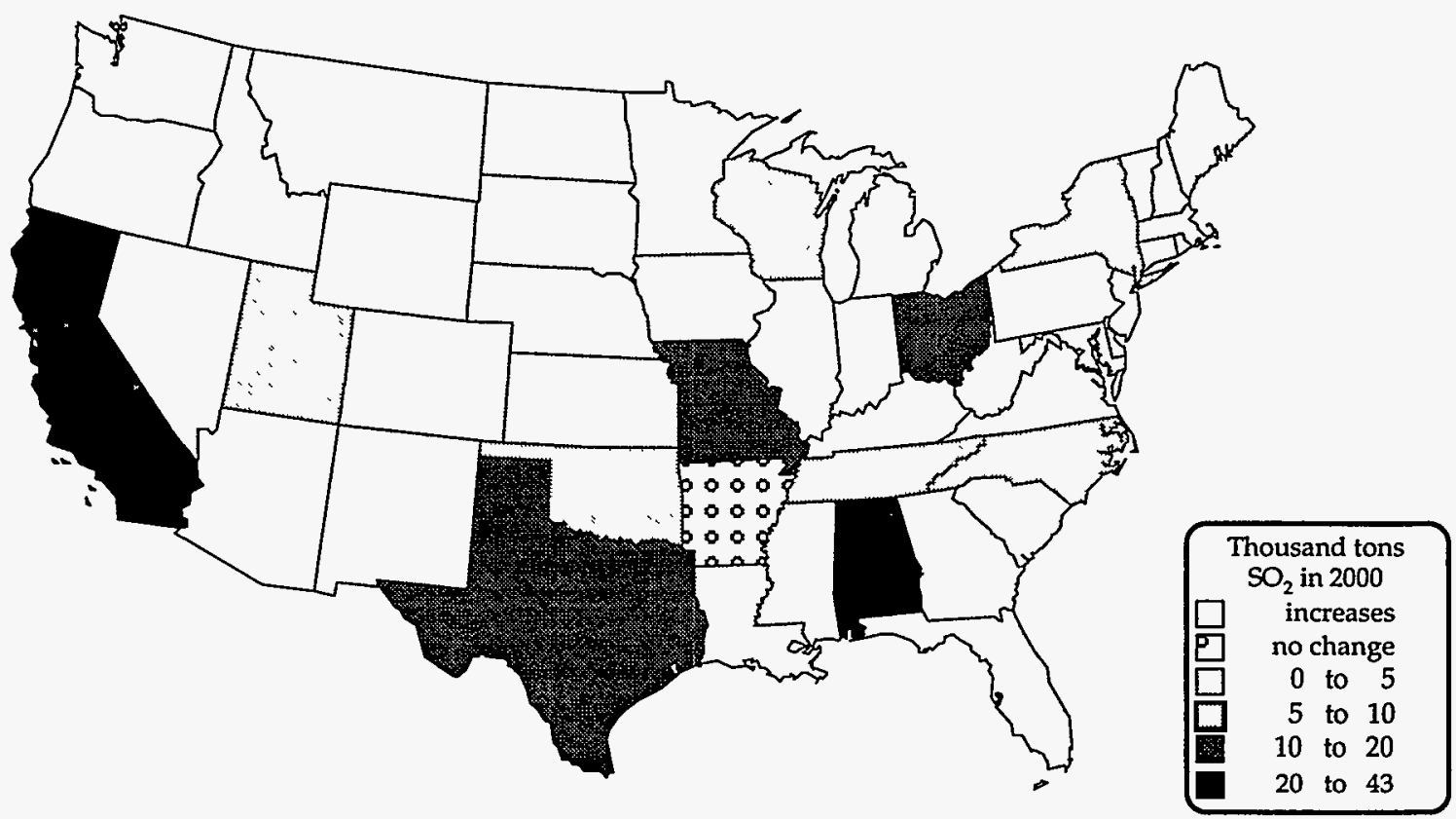

Figure 8. Decreases in base-case emissions when conservation occurs in all states. (States where emissions increased are blank; see Figure 7 for amount of emission increase. Emissions for utilities mapped to Arkansas did not change). 


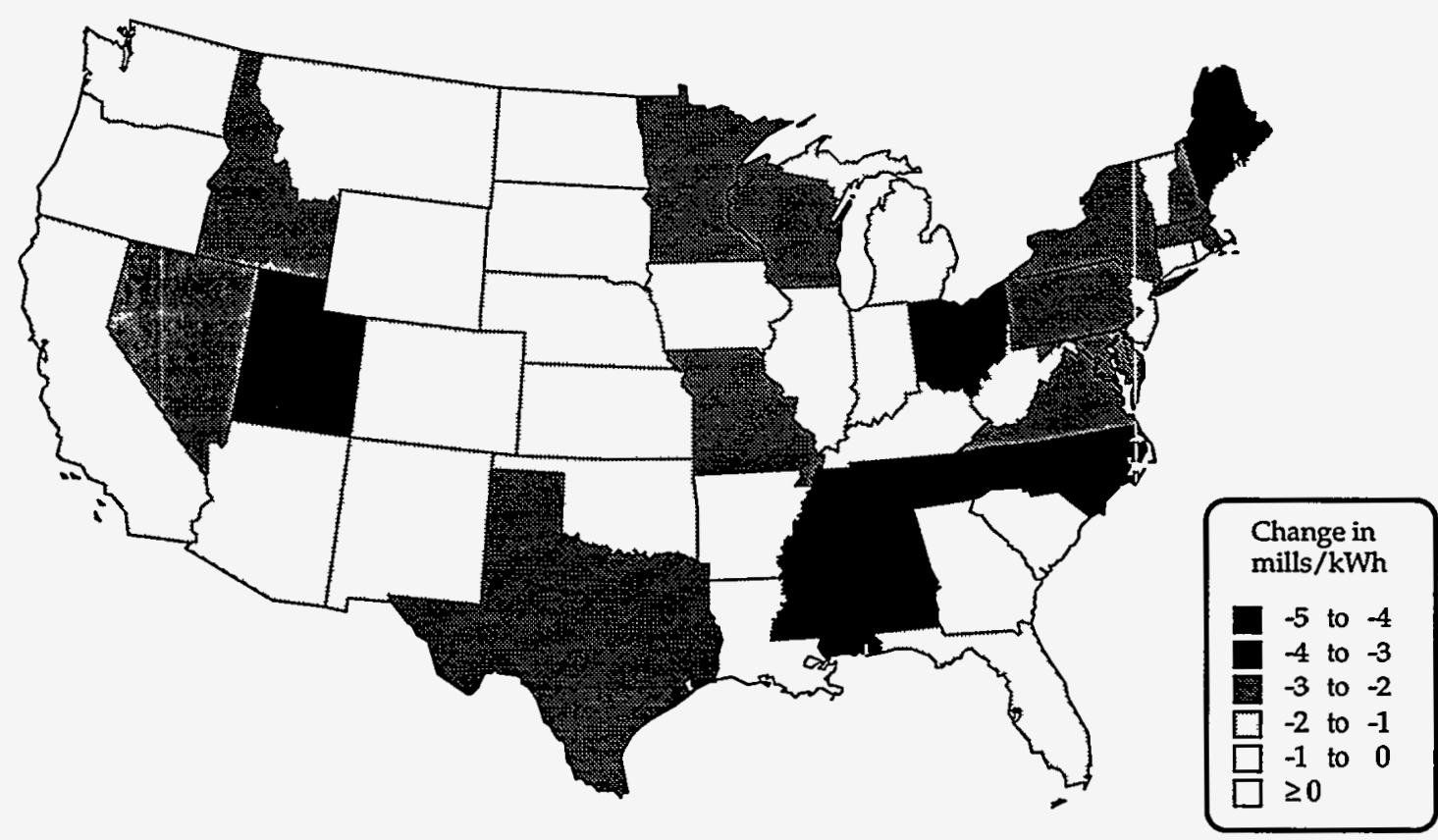

Figure 9. Change in base-case levelized electricity costs when conservation occurs in all states.

\section{INDIVIDUAL UTILITIES}

The second stage of our analysis was to estimate how compliance decisions, including the decision to improve end-use efficiency, might be affected by variations in the cost of an allowance. We chose two utilities for this stage of the analysis. One is a large utility system in the eastern Midwest that has coal-fired plants with a mix of high and low emission rates, with several plants subject to the Phase I reduction requirements. The other is a medium-sized utility system in the western Midwest whose plants with one exception have low to moderate emission rates. The first utility could reduce emissions at some of its plants to create enough excess allowances to bring its entire system into compliance without having to purchase allowances and, if it wanted, it could easily be a net seller of allowances. The second utility probably would find it more difficult to comply with the amendments and would either buy allowances or at most be a small net seller in the allowance market. The two utilities chosen thus represent a range that could illuminate how allowance prices might affect compliance decisions and how efficiency improvements might interact with these decisions.

The results presented below are illustrative, because although they use unitand utility-specific data, each of these utilities would have more detailed information about the costs of implementing different compliance options in its system, and it would consider variables other than cost and the need to comply with the Amendments. We have not consulted with the utilities either to obtain more detailed data or to check results. Some announced compliance decisions differ from those chosen by the model and are difficult to explain. For example, the large utility 
has announced that it will comply by adding scrubbers to one of its plants at a cost that far exceeds the $\$ 220-280 / \mathrm{kW}$ costs for scrubbing retrofits that the Electric Power Research Institute $(1984,1993)$ and EIA (1994) estimated from engineering models, or the $\$ 260 / \mathrm{kW}$ that EIA (1994) estimated from analyzing recent scrubber retrofits. We have run the model under a variety of assumptions, both for the 48 conterminous states and for this utility alone, and it always chooses fuel switching for this plant as a compliance measure, even at EIA's estimated costs for scrubbing.

When the model is run for a single utility, the model takes a narrow view of fuel markets, and it assumes that the utility can purchase as much natural gas or low-sulfur coal as it needs at the assiumed price. Thus results for an individual utility can differ from those for the same utility when the model is run for all utilities simultaneously. To structure these analyses, we ran a base case for each utility assuming that the market price of an allowance would be $\$ 450$ (levelized), and that no effort would be made to improve end-use efficiency. The utility would be free to buy or sell allowances at the assumed price, depending on its compliance costs relative to the allowance cost. We then ran four comparison cases for each utility, raising and lowering the price of an allowance by $\$ 100$ (levelized), and lowering the price by $\$ 200$ and $\$ 300$. We then allowed end-use efficiency improvement as an option, at the same levels assumed in the two scenarios discussed in previous sections, assuming the same allowance prices of $\$ 150, \$ 250$, $\$ 350, \$ 450$, and $\$ 550$. The allowance prices assumed are somewhat below the range expected shortly after the Amendments were passed, and the lower values are consistent with current expectations.

In the $\$ 450 /$ ton, constant efficiency base case, the model brings the large utility into compliance for 1995 by switching a large plant to low-sulfur coal; switching a smaller plant to similar coal brings the utility into compliance for the more stringent 2000 limits. The model would add new gas-fired capacity to meet demand in 1995, and new coal-fired capacity in 2000. In 2000, the model would purchase 117,000 allowances if they were available at the assumed $\$ 450$ price. Assuming a higher allowance price at $\$ 550$, the model would take the same compliance and expansion actions, but it also would add scrubbers to a third plant, and sell 45,000 allowances. For the lower allowance price of $\$ 350$, the model would bring the utility into compliance by switching the large plant to low-sulfur coal in 1995 as before, but it would purchase additional allowances rather than switch the second; 180,000 allowances would be purchased in all to obtain compliance. Capacity expansion would be the same as in the other two cases. If the price of an allowance were $\$ 250$, the model would switch less of the large plant to low-sulfur coal and increase the allowance purchases to 190,000 ; the capacity expansion would remain unchanged from the other cases. Dropping the price of an allowance to $\$ 150$ yielded the same compliance plan as the $\$ 250$ case, but the model replaced the gas-fired capacity in the expansion plan with a scrubber-equipped plant burning high-sulfur coal. Allowance purchases in the $\$ 150$ case rose to 193,000 . 
When improving end-use efficiency is an option, the model takes the same compliance action in the $\$ 450 /$ ton case as it does in the constant efficiency case, but the efficiency improvements would substitute for almost all of the gas-fired expansion that would otherwise occur; this would allow compliance with about 600 fewer allowances. For an allowance price of $\$ 550$, the model makes the same compliance decisions as it does for the $\$ 550$ constant efficiency case, and again substitutes efficiency improvements for additional gas-fired capacity; the utility sells about 400 allowances less than in the constant efficiency case. If the allowance price assumed for decision making is $\$ 350$, the model again purchases additional allowances rather than switching coal at the second plant, and it continues to substitute efficiency improvements for new gas-fired capacity. Reducing the allowance price to $\$ 250$ led to a slight reduction in coal switching at the large plant, as occurred in the constant efficiency case, and reducing the price to $\$ 150$ led to displacement of gas in the expansion plan with coal, again as occurred when conservation was not an option.

For the medium-sized utility, in the $\$ 450 /$ ton case without efficiency improvement, the model switches one plant almost completely to low-sulfur coal in 1995, switches the rest in 2000, adds a small amount of gas-fired capacity in 1995, and another small amount in 2000. The utility would have about 5,000 allowances to sell in 2000 at this price. These results do not change when the allowance price is increased to $\$ 550$ or decreased to $\$ 350$. Reducing the allowance price to $\$ 250$, however, switches the capacity added in 2000 from gas to coal, and reduces the allowances sold to 1,000 . Reducing the allowance price to $\$ 150$ causes a reduction in the amount of coal switching that occurs in 2000 and leads the utility to purchase nearly 15,000 allowances to cover the increased emissions.

Allowing this utility to improve end-use efficiency when the assumed allowance price is $\$ 450$, the model switches fuels at the same plant as before, substitutes the conservation for some of the gas-fired capacity to be built in 1995, and sells about 200 fewer allowances. Again, these results do not change when the allowance price is increased to $\$ 550$ or decreased to $\$ 350$. When the allowance price is decreased to $\$ 250$, the capacity added in 2000 switches from gas to coal as it does in the constant efficiency case, and the utility sells about 200 fewer allowances than when conservation is not an option. Finally, reducing the allowance price to $\$ 150$ again causes a reduction in the amount of coal switching that occurs in 2000 and leads to the purchase of $\mathbf{2 0 0}$ more allowances than in the constant efficiency case.

The results for these two utilities suggest that fairly large variations in allowance price are unlikely to affect compliance decisions, including the decision to improve end-use efficiency. However, when interpreting these results it is important to bear in mind the model's limited view of the natural gas market. The model assumes that natural gas will be available at the assumed cost. In fact, it is competition with other utilities that would bid up the price to the assumed level, and not every utility would be able to use as much gas as it would like. Thus in some cases conservation would displace coal-fired rather than gas-fired expansion. 
In these cases, improved end-use efficiency would affect the number of allowances traded by more than the results presented here would indicate, and it might affect compliance decisions where it did not in the cases examined here.

\section{GENERAL OBSERVATIONS}

From these and earlier results with the model we believe the price of an allowance is likely to be in the range of $\$ 300-400$ in 2000 (unlevelized 1990 dollars), probably nearer the lower end of this range because of our assumption that coalfired capacity will be the dominant option for meeting additional demand. Estimates by others are for allowance prices in the range of \$170-200 in 2000 (Energy Report 1993c; Energy Daily 1993a; EIA 1994), far below the $\$ 400-600$ that was typical of price expectations shortly after the Amendments were passed (Energy Report 1992a).

Under the emission tonnage cap, the most attractive options for reducing emissions are those that yield large tonnage reductions at relatively low costs/ton. Examples include adding scrubbers to very dirty plants (as in the Ohio River basin); switching some such plants to burn natural gas; repowering with "clean coal" technologies, in principle; and low-cost efficiency improvements, in principle. We qualify the last two options with "in principle" because the "clean coal" technologies are still being demonstrated at commercial scale, so their performance and cost remain uncertain; and because the size of emission reduction required of the utilities with the most emissions would require larger efforts to improve end-use efficiency than any utility is now making, if this were the only option available. On average, utilities must reduce their emissions by $43 \%$. Because of the large reductions required, conservation alone probably will not reduce $\mathrm{SO}_{2}$ emissions to compliance levels. As we have demonstrated, improvements in efficiency may shift emissions between regions, once emissions are under the cap, and in most cases these regional shifts are likely to be small. For utilities with high levels of emissions, conservation may be more important in maintaining compliance with the emission cap than with attaining compliance.

The limit on aggregate emissions and the accompanying allowance trading system will require that many people change the way that they view energy conservation. Under an emission rate limit, reducing demand for electricity reduced generation and emissions. This result provided some consumers with a moral rather than economic incentive to conserve. With an emission cap and allowance trading, reducing demand for electricity may reduce generation but, unless emissions are lower than the emission cap, it need not reduce emissions. The utility may trade the emissions internally, shifting emissions among its plants or divisions so that there is no clear local reduction in emissions, or it may trade the emissions with a distant utility; moving the emissions from one region to another, as occurred with Georgia in the two scenarios. This possibility weakens the previous moral incentive. In theory utilities should not be expected to reduce emissions below the cap, although some analysts have suggested the possibility that emissions may fall well below the cap after 2000 as utilities that retire existing 
generating capacity replace it with clean coal or other low-emission technologies (Energy Report 1993). However, widespread life extension of existing capacity, as assumed in one of scenarios in the NAPAP assessment (1991) could delay such a result for several decades.

A moral incentive to conserve may not actually change much end-use behavior. However, public reaction to announcements of early allowance trades suggests that many people view the allowance trading system in moral terms rather than in the economic ones of economists and the system's designers, and that they do not like the idea of buying and selling either pollution or clean air (Leone 1992; Hayes 1992; Knoxville News-Sentinel 1992a, 1992b, 1993; Energy Report 1993a). Some changes may be required in public education, in marketing of programs to improve end-use efficiency, or in marketing of compliance strategies if the emission trading system is to be acceptable to the public in its present form. Alternatively, it may be necessary to extend the emission trading system to incorporate concerns that go beyond economics, or to make other changes to the system to make emission trading more acceptable to the public. This is a topic for additional research.

Utility emissions of other gases, such as $\mathrm{NO}_{x}$, continue to be regulated under an emission rate standard, so that traditionally perceived links between conservation and emission reductions remain strong for them. Efficiency improvements also will reduce projected emissions of carbon dioxide, which as yet is unregulated. However, Title IV requires the EPA to study and report to Congress on the possibility of including $\mathrm{NO}_{x}$ within the emission trading system established . for $\mathrm{SO}_{2}$, several schemes have been proposed for trading carbon dioxide emissions, and the South Coast Air Quality Management District has established a trading program for several pollutants (Grubb 1989; Dwyer 1992; Solomon and Ahuja 1991). Thus the traditionally perceived links between conservation and other pollutants also could change. 


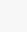




\section{ALLOWANCE TRADING IN PRACTICE}

The model used in the analysis in Chapter 3 assumes utilities will trade allowances to minimize the aggregate cost of reducing $\mathrm{SO}_{2}$ emissions, as the theory behind the trading system suggests. The results of the analysis suggest that improved end-use efficiency may interact only weakly with the allowance trading market: aggressive improvements had relatively small effects on allowance prices and, for at least two utilities, relatively large changes in allowance prices had small effects on compliance choices.

These conclusions must be interpreted in light of some of the modeling assumptions and data limitations noted in the discussions of the results. However, these conclusions also must be interpreted in light of the model's assumption that utilities will trade allowances as expected. In practice, allowance trading may be quite different from what theory suggests. Allowance trading is a new institution, so we do not know exactly how the new market will work or who will participate. However, as we discuss below, the information available suggests that initially the new market may not work as theory prescribes, and it probably will not work well at all at the start of Phase I in 1995. If so, then the effects of the allowance trading system on efficiency improvement and vice versa may be even smaller than our analysis in Chapter 3 suggests.

The principal reason for the anticipated divergence between theory and practice is that utilities do not appear to be behaving as expected by designers of the allowance trading system. This divergence may reflect a limited expectation of how utilities should act. First, some key regulations implementing Title IV were not issued until 1993, so utilities did not yet know the all of the rules of the new system in time to incorporate them into their decision making (Leone 1992). Some observers, however, have suggested that state regulations implementing Title IV do not offer utilities much incentive to trade (Bohi 1994). Second, utilities may be risk averse and less willing to use a new, untested institution such as emission trading than well-understood compliance options. Whether or not utilities are risk averse, Title IV and other government activities accommodate behavior that has the appearance of risk aversion. Third, the allowance trading market is likely to include decision makers in addition to utilities. We discuss each of these reasons below.

\section{INCOMPLETE REGULATIONS}

Most states have not yet established procedures for treating allowances in ratemaking. The state of Ohio began to solicit input on how to begin thinking about these questions only in January of 1992, and at the time was praised for being the 
first to do so (Lobsenz 1992b). As of March, 1994, public utility commissions in only seven states had issued guidance on how to treat $\mathrm{SO}_{2}$ allowances in ratemaking (Energy Report 1994a), even though 21 states have generating capacity subject to Phase I emission reductions. The Federal Energy Regulatory Commission proposed accounting rules dealing with allowances in December 1992 but did not issue final rules on including allowances in its Uniform Systems of Accounts until late March, 1993 (O'Driscoll 1992a, 1992b; Energy Report 1994a; Burkhart 1993); this was only part of the guidance that the Commission ultimately must provide on the treatment of allowances in ratemaking (Rose et al 1993). Any of these rules and regulations can be structured to make allowance trading more attractive or less attractive to utilities, and to encourage or discourage utilities in integrating allowance trading with other aspects of their planning processes. The delay and incompleteness in issuing this guidance increases uncertainty for utilities and probably will discourage allowance trading until it is resolved.

The Internal Revenue Service (IRS) did not issue regulations on tax treatment of allowances until March, 1992, and then only to cover the allowance allocations made by EPA under the formulas spelled out in Title IV (Lobsenz 1992c). The IRS did not rule on the tax treatment of purchases or sales of these allowances until November of that year (Lobsenz 1992f).

Similarly, EPA did not issue some Title IV requirements for reducing $\mathrm{NO}_{x}$ emissions until March 1, 1994, nearly 2 years after the schedule set by the 1990 Amendments, and only 10 months before the effective date of Phase I (Lobsenz 1994). Other uncertainties arose in coordinating Title IV with other titles of the Amendments and with state air quality regulations, where $\mathrm{NO}_{x}$ reductions may be required to help urban areas meet standards for ozone (Lobsenz 1992a). The National Park Service has proposed requiring offsets in existing emissions if new emission sources are allowed within $200 \mathrm{~km}$ of the Great Smoky Mountains National Park, and some have suggested that this may interfere with the allowance trading program (Cooney 1992).

Some of EPA's own regulations for $\mathrm{SO}_{2}$ allowances were delayed, revised, or proposed for revision quite late in the period available for planning compliance with the Amendments' 1995 provisions. For example, the Amendments allow utilities to substitute units not subject to the 1995 provisions for units that are. EPA announced in July 1993 its decision to revise its regulations covering this option, after discovering unintended results in proposed compliance plans (Lobsenz 1993b). EPA issued revised regulations covering this option in September, 1993, and it planned to revise these regulations further in 1994 (EIA 1994). EPA's system for tracking allowances and the number held by each utility in its allowance "account" did not begin operating until mid March, 1994 (Energy Report 1994b); its completion was expected to encourage more trading.

Further complicating compliance planning was a disagreement between EPA and utilities about how to implement a provision of the Title that was intended to 
award bonus allowances and grant extension of compliance deadlines for utilities that made an early commitment to add scrubbers (Lobsenz 1992d). EPA contended that it was doing what the law required, but many utilities contended that the method increased uncertainty and discouraged scrubbing, and they developed a way to work around the features that they did not like about EPA's proposal. Bonus allowances were not actually allocated until March 31, 1993 (Kaplan 1993), although the utility plan for allocating them had earlier reduced much of the uncertainty about the size of the allocations.

Compounding the uncertainty that utilities experienced about what requirements they would have to comply with under Title IV is the possibility that some states or the federal government will, at some time during the next 10-15 years require reductions in emissions of $\mathrm{CO}_{2}$, methane or other greenhouse gases to deal with global climate change. This uncertainty further complicates planning for compliance with Title IV. For example, adding a scrubber typically increases plant heat rate and $\mathrm{CO}_{2}$ emissions/ $\mathrm{kWh}$ generated, (EPRI 1993; EIA 1994). On the other hand, improving end-use efficiency or repowering a generating unit with some form of integrated gasification-combined cycle technology could reduce them, although perhaps at a higher cost.

In retrospect, given the complexity of creating a new institution such as allowance trading, and the need for several years' lead time to plan, schedule, and implement investments in emission control equipment, it probably was unrealistic to expect utilities to behave as the designers of the allowance trading system assumed they would in the first year of the compliance period. As regulations are completed, as utilities gain more experience with the allowance trading system, and as they (presumably) gain more confidence in it, utilities may become more likely to use the system as intended.

Finally, some utilities are affiliates of larger holding companies and may trade allowances with other affiliated companies rather than in the open market, which they believe would be more expensive (O'Driscoll 1992a). To the extent this happens, utilities may not be deviating as much as it appears from what theory expects. Rather, the trades will be more difficult to discern and report (EIA 1994), and ultimately may occur at different prices than in the open market.

\section{RISK AVERSION}

Some concern has been expressed that utilities are risk averse and will overcontrol emissions, at higher cost to ratepayers, than they would if they participated fully in the allowance trading market. Utilities do seem to be cautious in their approach to the new institution of allowance trading. In part this reflects the absence of a number of key regulations required to clarify how the market will work and how the revenues and costs of allowance trading will be allocated and taxed, as discussed above. However it also reflects real uncertainties both about the cost and availability of allowances, and about some technical options for reducing emissions. 
The future market price of an allowance is unknown. As noted in Chapter 3, shortly after the Amendments passed, allowance prices were widely expected to be in the range of \$400-600 per ton, although some estimates were lower and higher than this range. A decision to retrofit a scrubber requires a long lead time, and within the first year after the Amendments' passage several utilities announced decisions to add scrubbers by 1995, probably based on analyses that assumed allowance prices in that range. More recent estimates of allowance prices have been under $\$ 200$ per ton, and some sales and auctions that the Amendments require EPA to hold have yielded prices less than $\$ 150 /$ ton (EIA 1994). Thus, it has been difficult for a utility to determine the cost of purchasing allowances and compare that cost with the costs of other compliance measures. It also has been difficult to determine the benefits of making emission reductions for the purpose of selling allowances. The New York State Energy Office performed an analysis suggesting that the pending retirement of some old plants with high emissions, coupled with the long useful lifetimes of scrubbers, would bring utility emissions well under the 8.9million ton cap after 2000 and that the allowances may command prices near zero by 2020 (Energy Report 1993). In addition, there are uncertainties about the effect that parties other than utilities may have on the allowance market if they enter it and purchase or sell allowances. Some of these are described in more detail in a section below.

Utilities also appear to be risk averse toward new "clean coal" technologies that might help them comply with Title IV. Some residual caution may remain from the industry's experience with nuclear power, and it seems unlikely that utilities will undertake widespread adoption of new technologies until they have seen successful commercial-scale demonstrations of these technologies at several sites under several different operating conditions. A recent survey found that a utility may adopt "clean-coal" technologies cautiously, by first testing a new technology at one installation and gaining experience with it before ordering similar technology for additional installations (Rezendes 1990). That study suggested that 5 to 10 years might be needed for "clean coal" technologies to penetrate the market for new generating capacity once they have been demonstrated and become commercially available. Under the demonstration schedule for the Department of Energy's Clean Coal Technology Program, demonstration might not be complete until the mid 1990s, utilities might place their initial orders for such equipment a few years later, and widespread adoption might lag by several more years, meaning that utilities might not order these technologies for compliance until 2003-2005. A compliance strategy that reduces emissions in 1995 by more than is required, banks the allowances for use in 2000 and later years, and defers technology choices until 2003-2005 might be an effective way of dealing with this aversion to technological risk, and we have obtained such results with the model.

\section{OTHER PARTICIPANTS IN THE MARKET}

Allowance trading was intended to reduce nationwide emissions of $\mathrm{SO}_{2}$ at minimum cost, and some public utility commissions and utilities genuinely want 
to make trading work toward that objective. However, other agencies may have additional objectives. For example, legislatures in several states have acted to require or influence utility compliance plans in ways that help protect their highsulfur coal-mining industries and employment (Egan 1991b, 1991c). These measures include tax credits for using local coal, subsidies or requirements for adding scrubbers, and extensive review of proposed plans to switch fuels. Other agencies may seek to use the new law to help clean up long-standing environmental problems. For example, if an area violates ambient air quality standards, a state might require owners of power plants within the area to reduce emissions and sell allowances, rather than allowing them to purchase allowances (Dozier 1991). Officials in Wisconsin and New York have considered restricting the sale of allowances, at least partly on environmental protection grounds (Energy Report 1993a). State environmental protection agencies are likely to undergo some shifts in thinking to accommodate the new national emission tonnage cap established by Title IV (Egan 1991a). Advocates of a free market in allowances might consider any of these measures as being unwarranted interference with the allowance market, but the states taking such measures may view them instead as broadening the market to consider local factors in addition to national economics. It is too early to determine how these tensions between local concerns and national economics will be worked out, or what mechanisms might be most effective for doing so. This is a topic for additional research.

EPA convened an Acid Rain Advisory Committee (ARAC) to provide input to the process of writing the regulations to implement Title IV. While attending several ARAC meetings, we heard members of utilities and public utility commissions express concerns about potential behavior of other third parties. Staff of some utilities expressed concern that coal companies and railroad companies might enter the allowance market, purchase allowances, and bundle the allowances with their services or products to influence utility purchases. At least one would-be brokerage firm sees this as an opportunity for both coal suppliers and utilities to hedge against uncertainty (Egan 1991d), as does a consulting firm (Energy Report 1992b).

Staff of other utilities at the meetings expressed concern that coal contracts allow a range of sulfur contents. These staff members noted that some suppliers delivered coal with sulfur contents near the low ends of these ranges during the 1985-1987 baseline period that the Title uses to calculate allowance allocations, and some expressed fear that these suppliers may begin delivering coal with sulfur contents near the high ends of the ranges. At least one vendor of emission control equipment is considering accepting allowances in partial payment for the equipment (Egan 1991a; Lobsenz 1992f); the potential exists for such a firm to develop some influence in the market over the compliance choices of utilities. Finally, the institutions for arranging trade of allowances remain uncertain. Possibilities range from the allowance auctions conducted for EPA by the Chicago Board of Trade, to a full-fledged futures market, (Lobsenz 1992e; Energy Report ), to negotiations similar to those involved in buying and selling real estate, with 
commissions to match. It seems likely that trading will involve a mix of trading institutions.

At present it is too early to determine whether any of these concerns are, in fact, justified. Even if they are not justified, the fact that some utilities have held them has probably contributed to the caution that utilities seem to be taking toward purchasing allowances as a compliance strategy. On the other hand, some of the allowance trades that have been announced have involved third parties (Rose et al 1993), so it can be argued that the presence of third parties also has helped stimulate trading.

\section{CONCLUSIONS REGARDING TRADING AND IMPROVED EFFICIENCY}

Although utilities have traded some allowances in order to comply with the 1995 Phase I requirements, and have announced some plans to trade allowances for the 2000 Phase II requirements, to date many fewer allowances have been traded than anticipated when Title IV was written. The primary explanation for the limited trading appears to be that the allowance trading system was new and imposed with a short lead time relative to the time required for various agencies to implement it and, most importantly, for utilities to become comfortable with allowance trading and the regulations that govern it. The smaller-than-expected level of trading suggests that interactions between emission trading and energy efficiency are likely to be even smaller than estimated in Chapter 3, at least for Phase I and possibly early Phase II. 


\section{OTHER INCENTIVES FOR END-USE EFFICIENCY}

In addition to the allowance trading system, Title IV also creates two other incentives for improved end-use efficiency. One operates directly to reward efficiency improvements with additional allowances, and the other operates indirectly via electricity prices.

\section{ALLOWANCE RESERVE FOR CONSERVATION AND RENEWABLE ENERGY}

In addition to the allowance trading system and emission tonnage limit, Title IV establishes a conservation and renewable energy reserve of 300,000 allowances to be distributed before 2000 . The reserve is established by taking 30,000 allowances per year from the 8.95 million to be allocated each year from 2000 through 2009 . Utilities can earn these allowances by adopting and implementing a "least cost energy conservation and electric power plan" (what is now becoming known as IRP) that meets certain requirements specified in the Title, and then implementing energy efficiency improvements in accordance with that plan. The Title also requires that the Department of Energy must certify that the plan has net income neutrality before it is eligible to earn allowances from the reserve. Electricity saved under such a plan can earn allowances from the reserve at a rate of .000002 ton $/ \mathrm{kWh}$, (or, equivalently, one ton $/ 500 \mathrm{MWh}$ ), a rate which is specified in the Title. This is equivalent to $\$ .0012 / \mathrm{kWh}$ if allowances trade at $\$ 600 /$ ton, or $\$ .004 / \mathrm{kWh}$ if they trade at $\$ 200 /$ ton. Utilities also can earn these allowances, at the same rate, by installing and operating renewable energy sources that are consistent with a qualifying plan. In both cases, measures can earn these allowances only if they became effective after January 1, 1992, and allowances may be allocated to a utility only until it becomes subject to the $\mathrm{SO}_{2}$ reductions required in Phase I or Phase II. Allowances are to be awarded under a first-come, first served basis.

Discussions at the ARAC meetings revealed widespread belief that utilities would qualify to earn more allowances than the reserve would hold, and that some form of rationing would be necessary to ensure that renewable generating sources, which require longer lead times than efficiency improvements, would receive a fair share of the 300,000 allowances that the Title sets aside. Such a ration was instituted.

The number of allowances in the reserve is deceptively small, relative to the reserve's potential impact. Given the earning rates specified in the legislation, $1.5 \times 10^{11} \mathrm{kWh}$ of qualifying conservation and renewable generation would be needed to exhaust the reserve; this is equal to $5.3 \%$ of the nation's total generation in 1991 or, over the five years of Phase I, roughly $1 \%$ of the nation's total generation (EIA $1992 b)$. Because there was much interest in qualifying for these allowances, 
especially in the first few years following passage of the Amendments, the real benefit of the reserve for promoting energy efficiency may be less in the number of kilowatt-hours conserved to earn allowances than in the incentive provided for utilities and states to implement IRP. Preparing and implementing good integrated resource plans is likely to have a much greater effect on promoting end-use efficiency and renewable resources than the $1 \%$ of generation that can earn the reserved allowances directly. These effects will continue to be felt after all of the allowances in the reserve are allocated, or after the reserve program is terminated in 2000, whichever occurs first.

Despite this potential, the initial awards for conservation and renewable energy have been small, totaling only 930 through April, 1994, to 13 utilities (Energy Daily 1993b; Energy Report 1994c). These awards are for measures that yielded electricity savings in 1992. The measures that have earned these awards will, if maintained at the same level and verified, earn these same utilities the same number of allowances each year until the utilities become subject to emission reductions in 1995 or 2000 . It is also likely that some of these programs will expand. Thus, the initial awards probably give a false indication of future award rates. However, based on discussions with staff who oversee different parts of the allowance reserve program, it is possible that the initial interest in earning allowances from the reserve has declined because of the size of the reduction required in order to earn an allowance, and because present expectations of future allowance prices are much lower than those expected several years ago. In addition, the process of certifying that a utility's IRP process meets requirements specified in the Amendments, including net income neutrality, has proved to require more information and involve greater complexity than was originally expected.

Although the conservation bonus reserve may stimulate IRP and improvements in end-use efficiency, the allowance trading market is likely to make such planning more complicated. The price of an allowance is yet another variable for utilities to consider as they formulate plans, and a change in this price can affect the choice of environmental compliance measures, the amount of conservation to be acquired, or the type of technology to be chosen for increasing generation (Wile 1991). As our model results show, conservation itself can affect the price of an allowance, and decisions by some utilities can affect all utilities, although over all these effects are likely to be small. Many studies suggest that there are opportunities for investing in efficiency improvements that would be cost-effective even without the cost of complying with the 1990 Amendments (e.g., Pirkey and Scheer 1988; Gellings et al 1991). These investments presumably would be at costs below those where allowance prices might affect the investment decision, and they therefore should be undertaken in any event. However, some more expensive investments might need to be evaluated over a range of allowance prices to determine their sensitivity to the allowance trading market. 


\section{PRICE EFFECTS}

Compliance with Titles I, III, and IV of the Amendments is likely to increase the cost of using fossil fuels to generate electricity. Results from our model suggest that reducing $\mathrm{SO}_{2}$ emissions alone as required by Title IV could increase the levelized cost of electricity nationwide by .6 mills/ $\mathrm{kWh}$ (approximately .4 mills/kWh in unlevelized 1990 dollars), assuming a perfectly functioning allowance market and no additional improvements in end-use efficiency. Market failure would tend to increase the compliance costs. However, when we assumed aggressive improvement of end-use efficiency in all states, at a cost equivalent to $\$ 500 / \mathrm{kW}$ of capacity, the levelized cost of electricity nationwide decreased by 1.4 mills/kWh (levelized) rather than increasing. Thus we would expect low-cost efficiency improvements could offset much of the cost of complying with the Title's $\mathrm{SO}_{2}$ provisions even if efficiency is improved less aggressively than we assumed in our scenarios. Because our cost estimate is a national average, some utilities will have higher costs and could face real cost increases even with efficiency improvements. In addition, compliance with other titles of the Amendments could increase compliance costs beyond what we have estimated, especially for utilities that serve cities that fail to meet ambient air quality standards.

Over the long run, these higher costs are likely to lead consumers to use less electricity, either by substituting improved efficiency for electricity consumption or, if electricity prices rise relative to those of competing forms of energy, by substituting other fuels. However, the price and substitution effects seem likely to be small. Recent estimates suggest that the long-run price elasticity for residential electricity demand in the US is in the range of .38-.66 (Morss and Small 1989; Westley 1992). A .4 -mill increase in electricity costs corresponds approximately to a $.5 \%$ increase in the present nationwide average price of electricity (EIA 1992a), suggesting that over the long term consumption would be about $0.2-0.3 \%$ less than it would have been in the absence of the price increase if adjustment occurs entirely through market mechanisms. Because some residential efficiency improvements are economically justifiable now even without Title IV, state- and utility-sponsored conservation programs that promote additional improvements may be correcting for past market failures as well as responding to the costs of complying with the Amendments, thereby making it very difficult to sort out the price effect of compliance.

Nationwide, however, the cost of complying with the Amendments seems likely to provide only a small incentive for customers to improve their end-use efficiency. Again, some companies will experience higher costs than the nationwide average, and their consumers may have greater incentive than these aggregate estimates indicate. Others will have smaller cost increases.

Finally, as two authors of Title IV point out, the Amendments do not require utilities to reduce emissions until 1995 or, in many cases, 2000 (Markey and Moorhead 1991). Therefore, any price effects of compliance are likely to be delayed. These authors note that they promoted the conservation bonus allowance reserve 
precisely because they wanted the Amendments to provide incentives for improved efficiency sooner than the longer-term schedule for reducing emissions. 


\section{CONCLUSIONS}

The Clean Air Act Amendments of 1990 provide several incentives for improving energy efficiency. The most significant of these is likely to be the emission cap, which provides incentives for utilities to reduce the rate of growth in electricity generation. A bonus allowance reserve offers utilities additional incentive to increase energy efficiency and seems likely to stimulate greater use of IRP, although its direct rewards to utilities now may be less attractive than originally anticipated. Through such planning, the reserve ultimately may stimulate greater investment in both supply and end-use efficiency. Finally, higher electricity prices as utilities bring their present systems into compliance with the $\mathrm{SO}_{2}$ limitations of the Amendments will provide some long-run incentive for consumers to use electricity more efficiently, although this effect alone is likely to be quite small and could be offset by widespread increases in utility programs to improve end-use efficiency.

It is too early to say how large an effect these incentives will have. Although we have developed a model of emission trading, we also know that the amendments do not act in isolation. It is clear, both from theory and from public reaction to recent announcements of emission trades, that the traditional belief that conservation contributes to environmental protection must be reexamined in light of emission trading. Under emission trading, efficiency improvements may become a way of reducing monetary but not necessarily environmental cost of energy production and use. Additional research is needed to understand public attitudes toward emission trading and energy efficiency, and to suggest ways to improve public acceptance of emission trading systems.

Finally, there recently has been increased interest in retail wheeling and other measures to reduce regulation and increase competition within the utility industry. Because of the diversity of ways in which these changes in competition and regulation might take place, we have not attempted to assess how they may interact with allowance trading or efforts to improve energy efficiency. However, if such changes occur, they may have greater effect than allowance trading on utilities' interest in IRP and improving the end-use efficiency of their customers. As the direction and type of these changes becomes clearer, additional research would be warranted to examine these effects.

\section{ACKNOWLEDGMENTS}

We thank John Bennett of the U.S. Bureau of Mines, who supported development of the model used in the study. We also thank Gil Elliott, Tom 
Grahame, Eric Hirst, Cindy Jacobs, Ken Rose, and Barry Solomon for their comments on a draft of this report, and Diane Pirkey and Joe Kruger for answering questions. 


\section{REFERENCES}

Bohi, , Douglas R. 1994 "Utilities and State Regulators Are Failing to Take Advantage of Emission Allowance Trading," The Electricity Journal, Vol. 7, No. 2, March, pp. 20-27.

Burkhart, Lori A. 1993 " $\mathrm{SO}_{2}$ Emission Allowance Accounting Rules Adopted," Public Utilities Fortnightly, Vol..131, No. 9, May 1, p. 43.

Cooney, Cảtherine 1992 "Park Service Air Quality Plan Worries Coal, Utility Officials," The Energy. Daily, Vol. 20, No. 35, February 21, p. 6.

Dozier, Kimberly 1991 "EPA Allowance Trading On Collision Course with States?" The Energy Daily, Vol. 19 No. 81, 1991, pp. 1-2.

Dwyer, John P. 1992 "California's Tradable Emissions Policy and Greenhouse Gas Control," Journal of Energy Engineering, Vol. 118, No. 2, August, pp. 59-76.

Egan, John 1991a "Clean Air Act Imposes More Burdens on States that Lack Spare Cash," The Energy Daily, Vol. 19, No. 82, April 30, p. 5.

Egan, John 1991b "Ohio Cuts Acid Rain Pain, Saves Mining Jobs With Coal Tax Credit," The Energy Daily, Vol. 19, No. 127, July 3, 1991, pp. 1-2.

Egan, John 1991c "Clean Coal Grant Crucial for IP Clean Air Plan," The Energy Daily, Vol. 19, No. 138, July 19; p. 3.

Egan, John 1991d. "Compliance Poker Game Gears Up," The Energy Daily, Vol. 19, No. 197, October 11, pp. 1-3.

EIA 1991 Annual Outlook for U.S. Electric Power 1991. DOE/ELA-0474 (91).

Washington: U.S. Department of Energy.

EIA 1992a Electric Power Annual, 1990. DOE/EIA-0348(90). Washington: Energy Information Administration.

EIA 1992b Monthly Energy Review, June 1992 . DOE/EIA-0035(92/06). Washington: Energy Information Administration.

ELA 1993 Supplement to the Annual Energy Outlook 1993. DOE/ELA-0554(93). Washington: Energy Information Administration. 
EIA 1994 Acid Rain Compliance Strategies for the Clean Air Act Amendments of 1990. DOE/EIA-0582. Washington: Energy Information Administration.

EPRI 1984 Retrofit FGD Cost-Estimating Guidelines. EPRI CS-3696. Palo Alto, CA: Electric Power Research Institute.

EPRI 1993 Integrated Analysis of Fuel, Technology and Emission Allowance Markets. EPRI TR-102510. Palo Alto, CA: Electric Power Research Institute.

Energy Daily 1993a April 28, p. 5.

Energy Daily 1993b "EPA Awards Bonus Allowances for DSM Efforts," November 22, Vol. 21, No. 223, p. 3.

Energy Daily 1994 "EPA Awards Second Round of Allowances," Vol. 22, No. 84, May 4, p. 3

Energy Report 1992a "Final EPA rule gives green light to $\mathrm{SO}_{2}$ emissions trading market," Energy Report, November 2, pp. 727-8.

Energy Report 1992b "Sulfur emission credits seen as staple of coal industry management," Energy Report, October 19, p. 692.

Energy Report 1993a "Wisconsin may consider restrictions on trading of sulfur emissions," Energy Report, April 12, pp. 223-4.

Energy Report 1993b "New York Merc Exchange not yet sold on future of sulfur dioxide credits," Energy Report, May 3, 1993, p. 267.

Energy Report 1993c "Two utilities complain EPA could chill credit market with clean air decisions," Energy Report, September 13, pp. 532-3.

Energy Report 1994a "Utility regulators urged to consider emissions trading," Energy Report, March 7, pp. 127,129.

Energy Report 1994b "EPA emission tracking system on line," Energy Report, March 7, p. 133.

Energy Report 1993 "Scrubbers could be poor investment if credit-glut forecast is realized," Energy Report, June 28, p. 394.

Energy Ventures Analysis, Inc. 1986 "Evaluation of $\mathrm{SO}_{2}$ Emissions and the FGD Retrofit Feasibility at the 200 Top Emitting Generating Stations," U.S.

Environmental Protection Agency, Contract No. 68-01-6614, January 10, 1986.

EPA 1991 National Air Pollutant Emission Estimates 1940-1990. EPA-450/4-91-026. Research Triangle Park, NC: U.S. Environmental Protection Agency. 
Gellings, Clark W., Ahmad Faruqui, and Ken Seiden 1991 "Potential energy savings from efficient energy technologies," Energy Policy, Vol. 19, No. 3, pp. 217-230.

Grubb, M. J. 1989 The Greenhouse Effect: Negotiating Targets. London: Royal Institute of International Affairs.

Hayes, William C 1992 "All we can do is our best," Electrical World, Vol. 206, No. 7, July, p. 4.

Hillsman, Edward L., and Donald R. Alvic 1991 Estimating Costs of Electric Utility Compliance with Proposed Revisions to the Clean Air Act, ORNL/TM-11712, Oak Ridge National Laboratory, Oak Ridge, TN.

Hillsman, Edward L., and Donald R. Alvic 1994 The ORNL/UT/Bureau of Mines Electric Utility Model. Unpublished draft report. Oak Ridge National Laboratory, Oak Ridge, TN.

Hirst, E. 1993 Electric Utility DSM-Program Costs and Effects: 1991 to 2001. ORNL/CON-364, Oak Ridge National Laboratory, Oak Ridge, TN.

Hirst, E., C. Goldman, and M. E. Hopkins 1990 "Integrated Resource Planning for Electric and Gas Utilities," Integrated Resource Planning, volume 5 of Proceedings of the ACEEE 1990 Summer Study on Energy Efficiency in Buildings. Washington: American Council for an Energy-Efficient Economy, pp. 5-95-5-114.

Knoxville News-Sentinel, 1992a "Big Environmental News," Monday, May 18, p. A8.

Knoxville News-Sentinel, 1992b "Be a Leader, Not a Trader," Sunday, May 24, p. F2.

Knoxville News-Sentinel, 1993 "Brownie Points Earned by TVA," Monday, March 8, p. A8.

Kaplan, Daniel 1993 "EPA SO 2 Lottery Produces No Clear Winners," The Energy Daily, Vol. 21, No. 62, April 1, p. 2.

Leone, Marie 1992 "Washington Update," Power, Vol. 136, No. 6, June, p. 7.

Lobsenz George 1992a "Utilities Fight Costly $\mathrm{NO}_{x}$ Retrofits," The Energy Daily, Vol. 20, No. 9, January 14, pp. 1-2.

Lobsenz, George 1992b "Ohio Commission Starts Allowance Trading Effort," The Energy Daily, Vol. 20 No. 12, January 21, p. 3.

Lobsenz, George 1992c "Utilities Heartened by IRS Emissions Allowance Ruling," The Energy Daily, Vol. 20, No. 44, March 5, p. 3. 
Lobsenz, George 1992d "Kidder expects Allowance Trades by Summer," The Energy Daily, Vol. 20, No. 58, March 25, p. 3.

Lobsenz, George 1992e "CFTC Approves Futures Contract for $\mathrm{SO}_{2}$ Permits," The Energy Daily, Vol. 20, No. 77, April 22, pp. 1-2.

Lobsenz, George 1992f "Pure Air: Conservative Utilities Have Shunned Emissions Plan," The Energy Daily, Vol. 20, No. 83, April 30, p. 4.

Lobsenz, George 1992g "IRS Issues Tax Guidance On Emissions Allowances," The Energy Daily, Vol. 20, No. 213, November 5, pp. 1-2.

Lobsenz, George 1993a "EDF: New York Oversight Plan a Disaster for $\mathrm{SO}_{2}$ Trades," The Energy Daily, Vol. 21, No. 50, March 15, pp. 1-2.

Lobsenz, George 1993b "EPA Decision to Rewrite Acid Rain Rules Worries Utility Planners," The Energy Daily, Vol. 21, No. 148, July 28, p. 3.

Lobsenz, George 1994 "Court Date for EPA Acid Rain Rule?" The Energy Daily, Vol. 22, No. 42, March 4, p. 3.

NAPAP 19911990 Integrated Assessment Report. Washington: National Acid Precipitation Assessment Program.

Markey, Edward J., and Carlos J. Moorhead 1991 "The Clean Air Act and Bonus Allowances," Public Utilities Fortnightly, Vol. 127, No. 10, May 15, pp. 30-34.

Morss, M. F., and J. L. Small 1989 "Deriving Electricity Demand Elasticities from a Simulation Model," The Energy Journal, Vol. 10, No. 3, pp. 51-76.

O'Driscoll Mary 1992a "Utilities to FERC: Change Allowance Accounting Rule," The Energy Daily, Vol. 20, No. 71, April 13, pp. 1-2.

O'Driscoll Mary 1992b "APPA, NRECA Fault Allowance Accounting Plan," The Energy Daily, Vol. 20, No. 75, April 20, p 3.

Ottinger, Richard L., et al 1990 Environmental Costs of Electricity. New York: Oceana Publications, Inc.

Pirkey, D. B., and R. M. Scheer 1988 "Energy conservation potential: a review of eight studies." Proceedings of the 1988 ACEEE Summer Study on Energy Efficiency in Buildings," Washington: American Council for an Energy-Efficient Economy.

Rezendes, Victor S. 1990 Utilities' Potential Use of Clean Coal Technologies: Testimony before the House Subcommittee on Economic Stabilization, March 28, 1990. GAO/T-RCED-90-56. Washington, DC: U.S. General Accounting Office. 
Rose, Kenneth, Alan S. Taylor, and Mohammad Harunuzzaman 1993 Regulatory Treatment of Electric Utility Clean Air Act Compliance Strategies, Costs, and Emission Allowances. NRRI 93-16. Columbus, OH: National Regulatory Research Institute.

Solomon, Barry D., and Dilip R. Ahuja 1991 "International reductions of greenhouse-gas emissions: An equitable and efficient approach," Global Environmental Change, Vol. 1, No. 5, December, pp. 343-350.

Westley, Glenn D. 1992 New Directions in Econometric Modeling of Energy Demand with Applications to Latin America. Washington, DC: Inter-American Development Bank.

Wile, John 1991 "Impacts of the 1990 Clean Air Act on Utility Planning," The Electricity Journal, Vol. 4, No. 7, August/September, pp. 46-53. 
ORNL/CON-400

\section{INTERNAL DISTRIBUTION}

1. D. Bauer

2. L. Baxter

3. V. D. Baxter

4. L. Berry

5. D. S. Bjornstad

6. R. Braid

7. M. A. Brown

8. J. B. Cannon

9. F. C. Chen

10. J. Christian

11. G. Courville

12. T. R. Curlee

13. P. D. Fairchild

14. W. Fulkerson

15. S. Hadley

16. L. J. Hill

17. E. Hillsman

18. E. Hirst

19. P. J. Hughes

20. J. O. Kolb

21. M. A. Kuliasha
22. R. Lee

23. P. Leiby

24. J. M. MacDonald

25. V. C. Mei

26. W. R. Mixon

27. S. Purcker

28. D. E. Reichle

29. D. T. Rizy

30. M. Schweitzer

31. R. B. Shelton

32. B. E. Tonn

33. J. Van Dyke

34. J. Vancoevering

35. J. M. Veigel (ORAU)

36. D. L. White

37. T. J. Wilbanks

38. ORNL patent Office

39. Central Reserach Section

40. Document Reference Section

41. Laboratory Records (RC)

43-45. Laboratory Records Dept.

\section{EXTERNAL DISTRIBUTION}

46-50. Donald R. Alvic, Energy, Environment, and Resources Center, University of Tennessee-Knoxville, 10521 Research Drive, Suite 100, Knoxville, TN 37912

47. Richard H. Ball, Office of Environmental Analysis, PO-60, Room 4G-036, U.S. Department of Energy, 1000 Independence Avenue, Washington, DC 20585

48-50. Dr. John B. Bennett, U.S. Bureau of Mines, MS-5204, 810 7th Street, NW, Washington, DC 20241

51. Dr. Douglas R. Bohi, Director, Energy and Natural Resources Division, Resources for the Future, 1616 P Street, N.W., Washington, DC 20036

52. Bill Breed, Office of Environmental Analysis, PO-60, Room 4G-036, U.S. Department of Energy, 1000 Independence Avenue, Washington, DC 20585

53. David Conn, Environmental Design and Planning, Virginia Polytechnic Institute and State University, Blacksburg, VA 20461

54. Dr. Thomas E. Drabek, Professor, Department of Sociology, University of Denver, Denver, CO 80208-0209

55. Greg Elmes, Department of Geology and Geography, West Virginia University, Morgantown, WV 26506-6300

56. Ms. Cindy Jacobs, Connecticut Department of Public Utility Control, 1 Central Park Plaza, New Britain, CT 06051 
57. Calvin MacCracken, President, Calmac Manufacturing Corporation, 101 West Sheffield Avenue, P.O. Box 710, Englewood, NJ 07631

58. John Reed, Evaluation Manager, Wisconsin Demand-side Demonstrations, Inc., 2901 West Beltline Highway, Suite 307, Madison, WI 53713-4226

59. Jacqueline B. Shrago, Director, Office of Technology Trasnfer, 405 Kirkland Hall, Vanderbilt University, Nashville, TN 37240

60. Mr. George F. Sowers, P. E., Senior Vice President, Law Companies Group, Inc., 114 Townpark Drive, Suite 250, Kennesaw, GA 30144-5599

61. Dr. C. Michael Walton, Ernest H. Cockrell Centennial Chair in Engineering and Chairman, Department of Civil Engineering, University of Texas at Austin, Austin, TX 78712-1076

62-63. OSTI, U.S. Department of Energy, P. O. Box 62, Oak Ridge, TN 37831

64. Office of Assistant Manager for Energy Research and Development, DOE/ORO, P.O. Box 2001, Oak Ridge, TN 37831-8600

65-560. External Energy and Global Change Analysis Section distribution mailing list and extra copies to Connie Dagley, 4500N, G-23 